\title{
SOMOS INGOVERNÁVEIS? REFLEXÕES SOBRE O PRESIDENCIALISMO BRASILEIRO*
}

\author{
ARE WE UNGOVERNABLE? REFLECTIONS ABOUT THE BRAZILIAN PRESIDENTIAL SYSTEM
}

\section{Mariana Borges Martins da Silva**}

\begin{abstract}
Resumo:
Este artigo visa analisar o argumento da literatura jurídica que afirma que a separação de Poderes do sistema presidencialista brasileiro gera uma crise de governabilidade. Estudos recentes da ciência política demonstram que o Executivo não enfrenta resistência para implementar sua agenda no pós-Constituição de 1988, pois seria dotado de fortes poderes legislativos, de agenda e de controle da máquina pública. Neste artigo, faz-se uma revisão desta literatura sobre alguns mecanismos constitucionais que proporcionam um quadro claro da relação Executivo e Legislativo. Os poderes de agenda e legislativo do presidente brasileiro são analisados através do uso das Medidas Provisórias (MP), do poder de iniciativa orçamentária e do pedido de tramitação de urgência. Em relação à patronagem, considera-se sua influência para a formação do Governo e para o recrutamento dos legisladores. A competência do Legislativo de controle do Executivo também é analisada. A avaliação destes fatores institucionais revela um Poder Executivo que detém fortes poderes legislativos, de agenda e patronagem aliado a um fraco controle exercido pelo Legislativo. A ingovernabilidade não se confirma na prática e, assim, a demanda por reformas políticas passa a ser questionada.
\end{abstract}

Palavras-chaves: Governabilidade. Presidencialismo. Executivo. Legislativo. Separação de Poderes. Poderes de agenda.

\begin{abstract}
:
This article will analyze the argument that separation of power in the Brazilian presidential system creates a crises of governability. Recent Studies in Political Science shows the executive does not face any resistance in implementing its agenda during the constitution of 1988, because he has strong legislative, agenda setting power and the power to control the administration. This article reviews some of this constitutional mechanisms that depict a clear relationship of the Executive and the Legislative. The agenda and the legislative powers of the President are analysed
\end{abstract}

Este artigo foi baseado na Tese de Láurea intitulada "Presidencialismo no Brasil - uma análise da governabilidade nos Governos pós-Constituição de 1988”, desenvolvida sob a orientação do Prof. Elival da Silva Ramos, custeada com bolsa de iniciação científica da FAPESP e apresentada em outubro de 2007 perante o Departamento de Direito do Estado da Faculdade de Direito da Universidade de São Paulo. Devo um especial agradecimento ao Prof. Elival pela sua orientação neste e em tantos outros trabalhos científicos durante minha graduação e, acima, de tudo, por me fazer acreditar num ambiente acadêmico em que o debate de idéias é livre. Agradeço também a revisão feita por Laura Ponzoni, Camila Alves Saad e em particular Fernando Randau pelos preciosos comentários científicos e pelo título deste artigo.

Este artigo redatorial foi considerado do mais alto nível em informação e pesquisa, neste Sumário de 2008, pelo Editor, Antonio Augusto Machado de Campos Neto, desta Revista da Faculdade de Direito da Universidade de São Paulo.

** Mestranda em Ciência Política pelo Instituto Universitário de Pesquisas do Rio de Janeiro - IUPERJ e bolsista da CAPES. Graduada em Direito pela Universidade de São Paulo. E-mail: mbmsilva@iuperj.br. 
through the Provisional Measures, the right to propose the budget and the possibility to accelerate the legislative process. In relation to the control of the bureaucracy, we will look at its influence in the formation of the government and at the recruitment of the congressman. The competence of control of the Legislative over the Executive is also analised. The evaluation of these institutional factors shows that the Executive has strong legislative powers, agenda powers and the control of the bureaucracy, all that together with a weak control exercised by the Legislative. Therefore the nongovernability appears to be a myth. This casts doubt on the need for further reform on politic systems.

Keywords: Governability. Presidential system. Executive power. Legislative power. Separation of powers. Agenda power.

1. Introdução - separação de Poderes e sistema de Governo

Grande parte da doutrina jurídica classifica os sistemas de Governo segundo a separação de Poderes. Neste sentido, Executivo e Legislativo são independentes no presidencialismo enquanto que no parlamentarismo tais Poderes são, senão dependentes, harmônicos entre si. ${ }^{1}$

Com o advento do Estado Social, cresce a demanda por um Estado promotor de políticas públicas lideradas pelo Executivo, que é o Poder mais propício institucionalmente para tal função. Diante desta nova configuração do Estado, a tripartição de Montesquieu aplicada rigidamente no presidencialismo levou à constatação pela doutrina da inaptidão deste sistema para as novas funções sociais do Governo.

A doutrina majoritária afirma que, havendo cisão política entre Parlamento e Governo, aquele apenas deseja provocar o insucesso presidencial; gerando-se freqüentes situações de impasse. Não há o menor incentivo para a cooperação destes dois Poderes já que o único objetivo dos parlamentares é buscar o fracasso do Executivo para ganhar o Governo na próxima eleição. Além disso, como na eleição direta para presidente só há um único vencedor, o presidente é levado a crer que não é necessário construir uma base de apoio no Parlamento. ${ }^{2}$ Tal perspectiva é ainda mais grave na América Latina onde há

Há uma parte da doutrina jurídica que considera que mesmo no Parlamentarismo Executivo e Legislativo seriam independentes, apenas tal arranjo institucional proporcionaria uma maior harmonia entre eles (RAMOS, Elival da Silva. Uma nova Constituição: a proposta parlamentarista. Revista Bimestral de Investigação e Cultura CONVIVIVM, n. 25, p. 497.). Outra parte da doutrina, no entanto, afirma que tais Poderes, apesar de divididos entre si, não seriam sequer independentes (FERREIRA FILHO, Manoel Gonçalves. Curso de direito constitucional. 18 ed. São Paulo: Saraiva, 1990. p. 121 e MORAES, Alexandre de. Presidencialismo. São Paulo: Atlas, 2004. p. 60).

2 B. LAMOUNIER é um dos autores pessimistas frente à viabilidade democrática do presidencialismo: "O problema, naturalmente, é que não existem, no regime presidencialista, incentivos para a formação de uma base parlamentar viável (uma maioria estável, ou pelo menos, uma minoria substancial, que possa ser acrescida de outros apoios a um custo político razoável). LAMOUNIER, B. Estrutura institucional e governabilidade 
um risco ainda maior dessa situação de enfretamento culminar em um golpe institucional. ${ }^{3}$ Para os críticos do presidencialismo, a crise de Governo acaba por virar uma crise de regime, já que não há a flexibilidade encontrada no parlamentarismo de troca de Governo quando este perde a confiança do Parlamento. ${ }^{4}$

Em resumo, a separação rígida entre Executivo e Legislativo no presidencialismo - que se conjuga com a representação proporcional de lista aberta e baixa institucionalização dos partidos em alguns países da América Latina, - leva grande parte da literatura a atribuir a esse sistema a causa da instabilidade democrática dos países que a adotaram. ${ }^{5}$ A separação de Poderes se tornou sinônimo de crise de governabilidade. Este quadro levou a doutrina brasileira a defender tanto a adoção do sistema parlamentarista quanto reformas no sistema eleitoral e partidário, pois seria impossível obter governabilidade com partidos fracos, com congressistas paroquiais e com um sistema de separação rígida entre os Poderes.

Contudo, estudos sobre o funcionamento dos diferentes sistemas presidencialistas nos últimos anos, inclusive no Brasil com o trabalho de Limongi e Figueiredo, ${ }^{6}$ constataram que, mesmo nos países de presidencialismo "puro", como nos Estados Unidos, Executivo e Legislativo interagem para promover as políticas públicas sendo o presidente o ator proeminente desta relação. Outros mecanismos institucionais, que não apenas a separação de Poderes, o federalismo e o sistema eleitoral, foram destacados para demonstrar que a cooperação do Parlamento com o Executivo nos sistemas presidencialistas ocorre de forma muito mais positiva do que afirmado pelos seus críticos. Os principais fatores citados por esta literatura são os poderes legislativos dos

na década de 1990. In: VELLOSO, J. P. dos Reis (Coord.). O Brasil e as reformas políticas. Rio de Janeiro: José Olympio, 1992. p. 45.

3 Segundo B. ACKERMAN: “(...) Generations of Latin liberals have taken Montesquieu's dicta, together with America's example, as an inspiration to create constitutional governments that divide lawmaking power between elected presidents and elected congresses - only to see their constitutions exploded by frustede presidents as they disband intransigent congress and install themselves as caudillos with the aid of the military and/or extraconstitutional plebiscites. From a comparative point of view, the results are quite stunning. There are about thirty countries, mostly in Latin America, that have adopted American-style systems. All of them, without exception, have succumbed to he Linzian nightmare at one time or another, often repeatedly. Of, course, each breakdown was associated with a million other variables, but as Giovanni Sartori puts it, this dismal record 'prompts us to wonder wheter their political problem might not be presidentialism itself'. (grifos nossos) ACKERMAN, Bruce. The new separation of powers. Havard Law Review, v. 113, n. 3, p. 646, jan. 2000. Ver também MAINWARING, S.; SHUGART, M. S. (Orgs.). Presidentialism and democracy in Latin America. Cambridge, 1997. p. 31.

4 MAINWARING, S.; SHUGART, M. S. (Org.). Presidentialism and cit. (nota 3 supra), p. 30.

5 SARTORI, G. Neither Presidentialism nor Parliamentarism. In: LINZ, J. J.; VALENZUELA, A. The failure of presidential democracy. Baltimore/London: Johns Hopkins University, 1994. p. 197 e ACKERMAN, B. The new separation cit. (nota 3 supra), p. 663.

6 FIGUEIREDO, Argelina Cheibub; LIMONGI, Fernando. Executivo e Legislativo na nova ordem constitucional. Rio de Janeiro: FGV, 1999. O primeiro e principal trabalho que chamou atenção para novos aspectos do sistema presidencialista brasileiro. 
Executivos presidencialistas, os poderes dos líderes partidários frente a sua bancada, o poder de agenda do Governo e o controle do presidente sobre a máquina pública, também denominado de patronagem.

Diante desta nova perspectiva, percebeu-se que, na verdade, as atuais democracias presidencialistas apresentam características que as distanciam muito do modelo teórico de separação rígida entre os Poderes. Limongi, citando os dados de Deheza, indica que 56,1\% dos Governos presidencialistas latino-americanos são formados por coalizões partidárias. ${ }^{7}$ A formação de uma base consistente de apoio parlamentar ao presidente é mais comum do que a literatura sempre supôs. Isto porque a premissa de que o único objetivo almejado pelos partidos seria o de obter a presidência e que, portanto, tudo fariam para o insucesso do presidente, é errônea. Há outros interesses em jogo e que podem ser determinantes para o apoio de diversos partidos ao Governo, tais como o controle de pastas ministeriais ou mesmo a simples influência na formação de políticas públicas. ${ }^{8}$ Isto põe por terra o clássico argumento de Linz de que o presidencialismo se assemelharia a um jogo de soma zero em que os objetivos dos políticos nele seriam apenas o de ocupar cargos. ${ }^{9}$

Logo, apesar de o presidente não depender do apoio direto do Parlamento para ser eleito, outros fatores institucionais levariam a constituição, na prática, de uma base de apoio partidária ao chefe do Executivo, mediante a formação de Governos de coalizão, estabelecendo-se o que a literatura chama de presidencialismo de coalizão. As diferenças tradicionalmente atribuídas aos sistemas presidencialistas e parlamentaristas passam, dessa forma, a serem relativizadas. Tanto sistemas presidencialistas quanto parlamentaristas podem apresentar Governos minoritários, como os primeiros também podem basear seus Governos em coalizões partidárias. Segundo Cheibub, Przeworski e Saiegh a freqüência dos Governos de coalizão em ambos os sistemas seriam as mesmas se não houvesse a possibilidade de antecipar as eleições no parlamentarismo; logo, a diferença dos dois sistemas em relação à formação de coalizões é apenas de grau e não de espécie. ${ }^{10}$ Diante dos comportamentos semelhantes encontrados em ambos os sistemas, nos parece correto o ponto de diferenciação entre eles trazido pelos referidos autores:

(...) Procurando descobrir as diferenças institucionais entre os dois sistemas que poderiam afetar os incentivos para a

LIMONGI, Fernando. Formas de Governo, leis partidárias e processo decisório. Revista Brasileira de Informação Bibliografia em Ciências Sociais, São Paulo, n. 41, p. 12, 1996.

8 Idem, p. 12.

9 Presidential or parliamentary democracy, does it make a difference: the case of Latin America. Baltimore/ London: Johns Hopkins University, 1994. p. 3-87.

10 CHEIBUB, José Antonio; PRZEWORSKI, Adam; SAIEGH, Sebastian. Governos de coalizão nas democracias presidencialistas e parlamentaristas. Dados: revista de Ciências Sociais, Rio de Janeiro, v. 45, n. 2, p. $187-$ 218, 2002. 


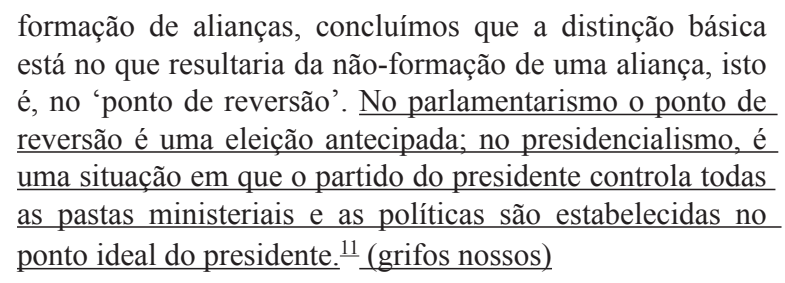

Tendo em vista este quadro de aproximação do funcionamento do sistema parlamentarista e presidencialista, neste artigo, faremos um pequeno levantamento desta literatura aplicada ao caso brasileiro. Para tanto, escolhemos alguns mecanismos constitucionais que proporcionam um quadro claro da relação Executivo e Legislativo após a Constituição, de 1988. Analisaremos os poderes de agenda e legislativo do presidente brasileiro através do uso das MPs, do poder de iniciativa orçamentária e do pedido de tramitação de urgência. Em relação à patronagem, estudaremos sua influência em relação à formação do Governo e ao recrutamento dos legisladores. E, finalmente, dentro destes aspectos citados e da competência do Congresso Nacional de sustar atos do Executivo que exorbitem o poder regulamentar ou os limites da delegação legislativa, faremos uma breve análise sobre o controle do Executivo feito pelo Legislativo.

Como o exame destes mecanismos demonstrará, o Poder Executivo detém fortes poderes legislativos, de agenda e patronagem. Alie-se a isso um fraco controle exercido pelo Legislativo. Tudo isso coloca em questão o argumento da ingovernabilidade e da demanda por reformas políticas a ela associada. E, ao mesmo tempo, outro ponto se levanta, qual foi o custo de desempenho democrático que pagamos por esta governabilidade?

11 CHEIBUB, José Antonio; PRZEWORSKI, Adam; SAIEGH, Sebastian. Governos de coalizão nas cit. (nota 10 supra), p. 189. No mesmo sentido SANTOS, Fabiano. Governos de coalizão no sistema presidencial - o caso do Brasil sob a égide da Constituição de 1988. In: AVRITIZER, L.; ANASTASIA, F. (Org.). Reforma política no Brasil. Belo Horizonte: UFMG, 2006. p. 224. 


\section{A dominação do executivo pós-Constituição, de 1988}

Antes de nos aprofundarmos na prática da relação Executivo/Legislativo, cumpre-nos contextualizar brevemente a opção do Constituinte em relação ao sistema de Governo. ${ }^{12}$ Apesar de um tanto quanto paradoxal, ${ }^{13}$ o desenho institucional do sistema de Governo na Constituinte respondeu a duas exigências históricas daquele momento, quais sejam: (i) o fortalecimento dos poderes do Legislativo, seja pela tendência à adoção do parlamentarismo, ${ }^{14}$ seja em resposta ao período imediatamente anterior que havia suprimido muitas de suas prerrogativas, e (ii) o fortalecimento do Executivo diante do temor de um quadro de paralisia decisória, semelhante ao ocorrido sob a égide da Constituição, de 1946, e diante das novas finalidades impostas pela Constituição ao Estado ao optar pelo modelo de Estado Social. ${ }^{15}$ Na seguinte análise, verificaremos, a partir de cada mecanismo de interação, qual destes dois objetivos prevaleceu na prática.

12 Para um aprofundamento sobre as escolhas institucionais da Constituinte, seja do sistema de Governo e outros temas, vide: GOMES, S. O impacto das regras de organização do processo legislativo no comportamento dos parlamentares: um estudo de caso da Assembléia Nacional Constituinte (1987-1988). Dados: revista de Ciências Sociais, Rio de Janeiro, v. 49, n. 1, p. 193-224, 2006; SOUZA, M. Teixeira de. O processo decisório na Constituição de 1988 - práticas institucionais. Revista Lua Nova, n. 58, 2003.

13 "De um lado, os constituintes aprovaram uma série de medidas tendentes a fortalecer o Congresso, recuperando assim os poderes subtraídos do Legislativo ao longo do período militar. De outro lado, a Constituição de 1988 manteve muitos dos poderes legislativos de que foi dotado o Poder Executivo ao longo do período autoritário, visto que não se revogaram muitas das prerrogativas que lhe permitiriam dirigir o processo legislativo durante o regime militar." In FIGUEIREDO, Argelina Cheibub; LIMONGI, Fernando. Executivo e Legislativo na nova ordem constitucional. Rio de Janeiro: FGV, 1999. (nota 6 supra), p. 41.

14 Como é sabido tal, tendência só se modificou no último minuto da Constituinte com a Emenda Lucena, deixando a Carta de 1988 permeada de dispositivos tipicamente parlamentaristas.

15 Sobre a opção da Constituição de 1988 pela democracia social vide RAMOS, Elival da Silva. Perspectivas de evolução do controle de constitucionalidade no Brasil. 2005. TESE (Titular) - Faculdade de Direito, Universidade de São Paulo, São Paulo. Segundo o Autor, a opção da Constituinte pela democracia social ficou clara ao considerar a lei como instrumento de promoção da igualdade e, portanto, como instrumento de Governo. Nesta perspectiva, o constituinte teria se preocupado em garantir a eficiência do Governo e, apesar da adoção do sistema presidencialista, tudo isto teria sido evidenciado "pela ampla iniciativa legislativa assegurada ao presidente da República, que detém, aliás, iniciativa privada no tocante a medidas com implicação direta na despesa pública (art. 61, caput, e $\S 1^{\circ}$ ); pela possibilidade do Chefe do Executivo editar atos formalmente legislativos (medidas provisórias e leis delegadas - arts. 62 e 68) ou materialmente legislativos (art. 84, VI, a); pelo acolhimento de técnicas de aceleração do processo legislativo (arts. 58, § $2, \mathrm{I} ; \S \S 1^{\circ}$ e $2^{\circ}$; e $66, \S, 6^{\circ}$ ); etc. A despeito de haver sido mantido o sistema de Governo presidencialista, presente, salvo um breve interregno, em todo o nosso período republicano, a preocupação com a eficiência do aparato governamental restou patenteada na Carta de 88 , provocando um certo temperamento na rigidez do modelo de separação de Poderes adotado. Pode-se mencionar a intensa participação Poder Executivo na atividade legislativa; a atribuição ao presidente da República da competência para editar regulamentos autônomos, em matéria de organização administrativa; a ampliação, em contrapartida, do controle político, normativo e não-normativo, a cargo do Congresso Nacional (arts. 49, V e X, e 58, §2, III, IV e V); e, também, a intensificação do controle jurídico sobre os atos de implementação de políticas públicas, sejam elas de natureza administrativa (arts. $5^{\circ}$, XXI, LXIX, LXX e LXXIII, e 129, III) ou legislativa (arts. 102, I, a, e 103). $\mathrm{O}$ Congresso Constituinte demonstrou sensibilidade quanto às dificuldades de se combinar, com sucesso, presidencialismo e democracia social, sendo certo que até mesmo autores simpatizantes do presidencialismo 


\subsection{Poderes de agenda e poderes legislativos}

\subsubsection{Medidas Provisórias}

A Medida Provisória talvez seja um dos institutos mais simbólicos da relação Executivo/Legislativo pós-Constituição de 1988. Ela significou uma tentativa de reforço do Poder Legislativo, se comparada aos Decretos-Leis (DL) da Constituição, de 1967, porém, na prática constitucional se revelou como um dos mecanismos que mais proporcionaram a dominação do Executivo no processo legislativo. ${ }^{16}$

O art. 62 da Constituição, de 1988, confere ao presidente a prerrogativa de editar MPs em caso de 'relevância e urgência' com força de lei. A principal diferença em relação ao DL, é que a MP é considerada rejeitada com o fim do prazo estabelecido para a sua apreciação pelo Congresso Nacional (art. 62, §3); outra diferença fundamental é a possibilidade dada aos parlamentares de emendarem o projeto do presidente. ${ }^{17}$ Ambas disposições são resultado do intuito de reforçar o papel do Legislativo em relação ao período anterior. $^{18}$

reconhecem que "há uma considerável tendência política para a adoção do parlamentarismo". (grifos nossos) p. 330-31.

16 Segundo A. C. Figueiredo: “A medida provisória é o mais poderoso instrumento legislativo facultado ao presidente, permitindo-lhe alterar resultados possíveis de acordo com a distribuição de cadeiras no Parlamento". (FIGUEIREDO, Argelina Cheibub. Agendas, instituições políticas e desempenho do Governo na democracia do Governo. In: REIS, E.; ZILBERMAN, R. (Org.). Retratos do Brasil. Porto Alegre: PucRS, 2004. p. 75). Também neste sentido, C. Pessanha: “A emissão pouco criteriosa de medidas provisórias desde a promulgação da Constituição e suas constantes reedições, que, em vários casos, ultrapassaram 80 , ou seja, sete anos, constituíram-se, mais uma vez, em uma delegação informal concedida ao Poder Executivo em detrimento do texto constitucional, e preservando o quase-monopólio da função legislativa pelo Executivo no Brasil". (PESSANHA, Charles. O Poder Executivo e o processo legislativo nas constituições brasileiras: teoria e prática. In: VIANNA, L. W. (Org.). A democracia e os três poderes no Brasil. Belo Horizonte: UFMG. Rio de Janeiro: IUPERJ/FAPERJ, 2002. p. 177.

17 Mesmo que não tenha feito expressamente, considera-se que o Legislativo tenha essa prerrogativa em virtude da tramitação da MP no Congresso, neste sentido C. Pessanha: "A tramitação da medida permite algo que não ficou claro no texto constitucional: a interferência do Congresso Nacional no seu conteúdo, mediante a introdução de emendas no projeto de lei de conversão. As modificações introduzidas pelo Poder Legislativo, entretanto, não gozam de vigência imediata. Sua validade depende da sanção presidencial e, por isso, é sujeita ao processo de veto e todas suas implicações. Essa faculdade pode ser considerada uma vitória do Legislativo, pois sua intervenção, além de não ser prevista no texto constitucional, conforme visto, é controversa." Id. Ibid., p. 174.

18 De acordo com C. M. Clève, as diferenças entre as MP e os DLs seriam: (i) diferentes pressupostos autorizadores; (ii) no DL o Executivo não podia aumentar as despesas públicas; (iii) a eficácia temporal da MP é de 30 dias enquanto que a do DL era de 60; (iv) a Constituição de 67 definia expressamente as matérias suscetíveis de adoção de DL (segurança nacional, finanças públicas e criação de cargos públicos e vencimentos), enquanto que o $\S 1$ do art. 62 da CF/88 apenas determina sobre quais matérias é vedado editar MP; (v) as MPs se não convertidas em lei no prazo perdem a sua eficácia desde sua publicação enquanto que os DL eram tidos por aprovados; (vi) possibilidade de apresentar emendas ao projeto no processo de conversão em lei da MP, o que era interditado no processo de aprovação do DL; (vii) antes da EC n. 32/2001, se a MP fosse rejeitada ou não aprovada dentro do prazo anular-se-iam os atos praticados sob a sua égide, 
Antes de expormos as conseqüências práticas das MPs para a relação Executivo-Legislativo, cumpre discorrer sobre o seu quadro legal antes e depois da Emenda Constitucional (EC) n. 32, de 2001. Uma vez editadas, as MPs são imediatamente submetidas à apreciação do Congresso Nacional por meio de uma mensagem presidencial instruída com uma Exposição de Motivos ( 11 do art. 2 da Resolução n. 1/2002, do Congresso Nacional). De acordo com o $\S 9$ do art. 62 da CF/88, uma Comissão Mista de deputados e senadores emite, dentro de quatorze dias, um parecer acerca da constitucionalidade, do mérito e da adequação financeira da MP antes de sua apreciação, em separado, pelas plenárias de cada Casa. É neste momento que são oferecidas emendas pelos parlamentares ao projeto de lei (Art. 4 caput e $\S 1$ da Resolução n. 1/2002 do Congresso Nacional). Este parecer é encaminhado à Câmara dos Deputados, conforme determina o $\S 8$ do art. 62 da CF/88 e acompanhado, se for o caso, do projeto de lei de conversão e do projeto legislativo referente à regulamentação das relações jurídicas decorrentes da vigência dos textos suprimidos ou alterados. ${ }^{19}$

Antes de deliberarem sobre o mérito da MP, ambas as casas devem apreciar o atendimento dos pressupostos constitucionais, $\S 5$ do art. $62 \mathrm{CF} / 88$. Se a medida não for apreciada em até quarenta e cinco dias, contados de sua publicação, entra em regime de urgência em cada uma das casas do Congresso, trancando a votação de todas as outras pautas, $\S 6$ do art. 62 da $\mathrm{CF} / 88$. A pauta só será liberada com a aprovação da MP ou a sua perda de eficácia com o decurso de prazo. ${ }^{20}$ Caso a MP não seja aprovada dentro desses sessenta primeiros dias, sua vigência será prorrogada por mais sessenta dias automaticamente, ou seja, sem a necessidade de reedição por parte do presidente. ${ }^{21}$ Sendo aprovada com alterações, será enviada à sanção do presidente da República. ${ }^{22}$ Se for aprovada sem alterações, considera-se dispensável a sanção presidencial. ${ }^{23}$

Com a EC n.32/2001, os atos praticados durante a vigência de MP rejeitada ou que tenha perdido sua eficácia permanecerão por ela regidos, caso não seja editado em até sessenta dias um decreto legislativo regulando-os. O intuito aqui foi o de preservar a segurança jurídica. ${ }^{24}$ Cumpre ressaltar que a Constituição, de 1967 , previa que os atos

enquanto que os atos praticados sob a égide dos DL continuavam válidos, mesmo com a sua rejeição; (viii) as relações jurídicas decorrentes de uma MP rejeitada devem ser reguladas pelo Congresso Nacional; o que não existia para os DL. (CLĖVE, Clérmeson Merlin. Atividade legislativa do Poder Executivo no Estado contemporâneo e na Constituição de 1988. 2. ed. São Paulo: Revista dos Tribunais, 2000. p. 158-59.

19 AMARAL JR., J. L. M. do. Medida provisória e sua conversão em lei - a Emenda Constitucional n. 32 e o papel do Congresso Nacional. São Paulo: Revista dos Tribunais, 2004. p. 245-46.

20 Id. Ibid., p. 250.

21 Id. Ibid., p. 253.

22 Id. Ibid., p. 255.

23 Id. Ibid.

24 Id. Ibid., p. 256. 
praticados sob a vigência de um DL permaneciam inalterados mesmo com a sua rejeição. ${ }^{25}$ Antes da EC n. 32/2001, as MPs deveriam ser apreciadas pelo Congresso Nacional em trinta dias, sob pena de perderem a validade e dos atos sob ela praticados serem considerados nulos. Contudo, havia a possibilidade de reedição ilimitada. Até a edição da EC em questão, o Executivo utilizou-se bastante da possibilidade de reedição das $\mathrm{MPs},{ }^{26} \mathrm{o}$ que na prática tornava irrelevante o prazo dado ao Congresso para apreciá-las. ${ }^{27}$

Ao lado disso, o Executivo ainda poderia recorrer a outros mecanismos para evitar que o Congresso votasse certas medidas polêmicas. Exemplo disso era o recurso à obstrução, em que a base do Governo negava o quorum necessário à votação da MP e depois a reeditava. ${ }^{28}$ Estes dois fatores conjugados fizeram com que o controle das MPs pelo Congresso fosse praticamente inexistente.

Mas, sobretudo, a MP, ainda antes da EC n. 32/2001, colocava o Executivo em uma posição estratégica dentro do processo legislativo. Isto porque sua edição altera imediatamente o status quo anterior e o Legislativo, ao apreciá-la, deve levar essa mudança em conta necessariamente, o que induz os parlamentares a cooperar. O que pode ser comprovado pelo baixo índice de rejeição de MPs pelo Congresso Nacional, apenas vinte até o ano de 2000 e metade delas por inadmissibilidade. ${ }^{29}$ De acordo com Limongi:

Trata-se de importante arma nas mãos do Executivo porque a edição de uma medida provisória implica a imediata alteração do 'status quo'. Ao analisá-la o Congresso não opta pelo 'status quo' anterior (SQ) e aquele a ser produzido pela promulgação da medida (SQmp), mas sim entre SQmp e uma situação em que a MP é rejeitada após ter vigorado

25 Sobe este aspecto J. L. do Amaral Jr.: "O novo modelo trouxe saudável evolução. Não tem o excesso da Emenda Constitucional n. 1/1969, que simplesmente mantinha os efeitos do decreto-lei rejeitado no período em que esse vigeu. A Emenda Constitucional n. 32/2001, diferentemente, permite ao Congresso Nacional (no prazo de até sessenta dias após a rejeição ou perda de eficácia da medida provisória) disciplinar, por decreto legislativo, as relações jurídicas decorrentes da medida provisória não convertida. A solução prestigia a segurança jurídica em detrimento de um modelo (o originário de 1988) que implicava, até mesmo, a desconstituição de eventual direito adquirido, porquanto o parágrafo único do art. 62 da Constituição de 1988 resultava, como visto, caso de retroatividade máxima". Id. Ibid., p. 258.

26 Segundo aufere-se da análise dos dados relativos às MPs trazidos por O. Amorim Neto e P. Tafner até 1999, grande parte das MPs eram reedições, fato que se deu sobretudo no Governo FHC (AMORIM NETO, Otavio; TAFNER, Paulo. Governos de coalizão e mecanismo de alarme de incêndio no controle legislativo das Medidas Provisórias. Disponível em: <http://www/scielo.br/pdf.dados/v45n1/a01v45n1. pdf>. Acesso em: 12 fev. 2007. p. 9-14).

27 Segundo F. Limongi “A reedição de MPs merecem uma análise mais detida. Concretamente significam que o Legislativo deixou de apreciá-las no prazo constitucionalmente previsto". (FIGUEIREDO, Argelina Cheibub; LIMONGI, Fernando; VALENTE, A. L. Governabilidade e concentração de poder institucional - o Governo FHC. Tempo social - revista de sociologia da USP, São Paulo, p. 55, out. 1999.

28 LIMONGI, Fernando. Executivo e Legislativo. op. cit. (nota 6 supra), p.51; no mesmo sentido SAMPAIO, M. A. S. A EC N. 32/2001 e o diálogo entre Legislativo e Executivo acerca da medida provisória. Disponível $\mathrm{em}:<\mathrm{http}: / /$ necon.iuperj.br/arquivos/artigos/artigo_sampaio.pdf $>$. Acesso em: 24 ago. 2007. p. 2-3.

29 Dados de AMORIM NETO, Otavio; TAFNER, Paulo. op. cit. p. 10. 
e surtido efeito (Mprej). Digamos que para a maioria dos legisladores a seguinte relação de preferência seja verdadeira: $\mathrm{SQ}>\mathrm{SQmp}>\mathrm{Mprej}$, onde o símbolo > significa 'é preferido a'. Logo, a maioria aprova a MP. Se fosse introduzida como um projeto de lei ordinária, a MP seria rejeitada. Por surtir efeito no ato de sua edição, o recurso à edição de MPs é uma arma poderosa nas mãos do Executivo. Os congressistas podem ser induzidos a cooperar. ${ }^{30}$

A EC n. 32/2001 teve a finalidade de combater os abusos praticados pelo Executivo com a possibilidade de reedição ilimitada fortalecendo-se, assim, a atuação do Congresso. Para tanto, o Executivo ficou impedido de reeditar as MPs. Todavia, o Executivo foi dotado de outros elementos que reforçaram o seu poder de agenda dentro da arena legislativa, através da nova regulamentação da MP. Um destes elementos foi a obstrução da pauta legislativa e a entrada da matéria tratada pela MP em medida de urgência, caso esta não tenha sido apreciada em quarenta e cinco dias ( $\$ 6$ do art. 62 da $\mathrm{CF} / 88$ ). Com isto, o Executivo acaba por determinar ao Congresso o que e quando votar. ${ }^{31}$ Para completar, a EC n. 32/2001 ainda garantiu a continuidade das relações jurídicas realizadas sob a égide de uma MP revogada ou que tenha perdido eficácia se o Congresso não emitir em até sessenta dias um decreto regulando-as ( $\$ 11$ do art. 62 da CF/88). Além do ganho em segurança jurídica, já ressaltado, essa medida reforçou ainda mais o poder das MPs em alterarem o status quo, ${ }^{32}$ pois, caso não seja editado este decreto, seus efeitos continuam em vigor.

Sampaio ainda ressalta que o Poder Legislativo teve a oportunidade com a EC n. 32/2001 de regulamentar os critérios do que sejam "relevância e urgência" e mesmo assim não o fez. ${ }^{33}$ Este silêncio, contudo, não foi um descuido. Ele decorreria da visão predominante entre os parlamentares de que tais critérios deveriam ser definidos pela subjetividade do presidente. ${ }^{34}$ Segundo este Autor, ${ }^{35}$ apoiado na análise da Amorim e Tafner, todas essas mudanças revelam que o Legislativo não considera que o Executivo esteja

30 LIMONGI, Fernando. Executivo e Legislativo. op. cit., p. 26.

31 Neste sentido, M. A. S. SAMPAIO, afirma que a EC n. 32/2001 não deve ser encarada como um enfraquecimento do Executivo devido à impossibilidade de reedição, muito pelo contrário, ela deve ser vista dentro do contexto do presidencialismo de coalizão em que o poder do Executivo "perdido de um lado, compensou-se do outro". SAMPAIO, M. A. S. A EC N. 32/2001 e o diálogo entre Legislativo e Executivo acerca da medida provisória. Disponível em: < http://necon.iuperj.br/arquivos/artigos/artigo_sampaio.pdf>. Acesso em: 24 ago. 2007. p. 7.

32 Id. Ibid., p. 8.

33 Id. Ibid.

34 Id. Ibid.

35 O referido Autor ainda cita em seu trabalho outras mudanças da EC n. 32/2001 que revelariam a confiança do Legislativo em relação ao Executivo no que tange as MPs, como a dispensa do Legislativo ser chamado às pressas para a análise de uma MP quando aquele se encontre em recesso ( $\$ 4$ do art. 62 da $\mathrm{CF} / 88$ ), as 'leis provisórias', assim chamadas as MPs editadas até a data da referida emenda e que foram mantidas 
usurpando a sua competência legislativa. Muito pelo contrário, todos estes mecanismos constitucionais e as mudanças introduzidas pela EC n. 32/2001 revelariam uma forma de delegação de poder do Legislativo ao Executivo, tudo com o expresso consentimento do Parlamento. ${ }^{36}$

Finalmente, o prazo maior de eficácia, de cento e vinte dias, favoreceu tanto Executivo quanto o Legislativo por meio dos mecanismos de "alarme de incêndio". De acordo com Amorim e Tafner, estes mecanismos consistiriam na verificação pelos parlamentares se as mudanças introduzidas pelas MPs são preferíveis ao status quo. Para tal, não seria necessário que os parlamentares possuíssem grandes conhecimentos técnicos ao avaliarem se uma MP é boa ou-não; bastaria escutar as partes afetadas pela MP. Logo, os "alarmes de incêndio" seriam medidas de controle relativamente fáceis de serem efetivadas. ${ }^{37} \mathrm{O}$ período de cento e vinte dias seria suficiente para que estes mecanismos pudessem funcionar no Congresso Nacional. Seria um espaço de tempo muito maior do que o dado anteriormente de trinta dias. Isto garantiria um tempo hábil para que o Congresso verifique os efeitos concretos da MP e acione os "alarmes de incêndio", caso seja necessário, sem que com isso corra o risco de usurpação desta sua competência com a reedição sucessiva da MP pelo Executivo. ${ }^{38}$

Isto é ainda mais plausível se considerarmos que cabe ao Congresso regular os efeitos de uma MP entre as datas de sua publicação e sua rejeição. Quanto maior, portanto, este prazo, maior o período que o Congresso tem para "escutar possíveis alarmes de incêndio acionados pelos grupos sociais afetados pela MP". ${ }^{39}$ Isto explicaria o porquê da demora do Congresso em votar algumas medidas consideradas relevantes, ${ }^{40}$ enquanto que tal não ocorre com os processos considerados de menor monta - como os assuntos específicos da Administração. ${ }^{41}$ Assim, a demora do Congresso em apreciar as MPs diz

até a manifestação em contrário do Parlamento e a possibilidade de regulamentação de novas emendas constitucionais por meio de MP.

36 "Tal reforço do poder de conformação da agenda legislativa, por meio de edição de medida provisória, em muito ainda se encontra nas mãos do Executivo. E isso, por manifestação de vontade do Congresso Nacional, consubstanciada na Emenda Constitucional n. 32/2001." (grifos nossos) (SAMPAIO, M. A. S. op. cit., p. 9).

37 AMORIM NETO, Otavio; TAFNER, Paulo. Governos de coalizão e mecanismo de alarme de incêndio no controle legislativo das Medidas Provisórias. Disponível em: <http://www/scielo.br/pdf.dados/v45n1/a01v45n1.pdf> . Acesso em: 12 fev. 2007. p. 19-22.

38 SAMPAIO, M. A. S. op. cit., p. 7.

39 AMORIM NETO, Otavio; TAFNER, Paulo. op. cit., p. 21.

40 O referido Autor cita um exemplo em que os "alarmes de incêndio" teriam sido acionados. Tratar-se-ia do pacote 51 do Governo FHC. Este Governo previa várias medidas para reduzir o déficit fiscal do país, dentre eles um aumento da alíquota do imposto de renda da classe média. A princípio, o Congresso havia proposto apenas ligeiras emendas, mas, devido à forte manifestação da classe média contrariamente a essa medida, o Congresso mudou a postura e passou a exigir uma revisão do pacote para aliviar a classe média. AMORIM NETO, Otavio; TAFNER, Paulo. op. cit., p. 21.

41 Id. Ibid., p. 21-22. 
respeito à maneira como o nosso legislativo procura superar os problemas da falta de capacitação técnica dos parlamentares e de sua assessoria. ${ }^{42}$ Tratar-se-ia, portanto, de uma forma de controle efetiva exercida pelo Congresso Nacional no que toca às edições de MPs pelo Executivo. O exercício de uma participação efetiva no controle das MPs ainda poderia ser comprovado pela relação positiva entre a taxa de coalescência de um gabinete presidencial e as alterações no texto das MPs, que analisaremos logo adiante.

A outra forma de controle do Congresso diz respeito à obstrução das MPs editadas pelo Governo. Isto porque, apesar de todo o poder de agenda dada pela MP ao Executivo, ela não passa sem o apoio da maioria. Se o Governo for minoritário e se as suas políticas não forem de modo algum convergentes com os interesses parlamentares, o presidente corre o risco de ver todas as suas medidas travadas pela oposição do Congresso. Neste caso, haverá o recurso às MPs originais, já que não há espaço para a coordenação entre Executivo e Legislativo no processo de aprovação da MP. Tal instrumento, antimajoritário, só seria efetivo em curto prazo. Exemplo típico desse fato, no Brasil, foi o Governo Collor. ${ }^{43}$

Diante deste quadro, Amorim e Tafner concluem que o recurso e o uso das MPs pelos Governos pós-Constituição, de 1988, não representam uma usurpação do Poder Legislativo do Congresso pelo Executivo. ${ }^{44}$ Este tipo de interação escapa dos instrumentos clássicos $^{45}$ de controle de um Poder sobre o outro, pois representam, na verdade, mecanismos específicos de interação entre eles desenvolvido pelo presidencialismo de coalizão brasileiro. Este controle se daria, sobretudo dentro da maioria parlamentar formada pelos gabinetes de coalizão, que serão analisados em detalhe nos próximos tópicos. É na interação entre a base de apoio parlamentar do Governo e o Executivo que se daria o controle do Legislativo sobre este último. Tanto é assim que distintos critérios de formação de Governo implicam diferentes padrões de relacionamento entre Executivo e Legislativo, os quais, por sua vez, afetam o modo de utilização de MPs originais, de MPs reeditadas com o texto modificado e de projetos de autoria do Executivo. ${ }^{46}$

42 Id. Ibid., p. 22

43 Id. Ibid., p. 28

44 Segundo eles, haveria três formas de se analisar as MPs pela literatura no que toca a relação entre Executivo e Legislativo: (i) tratar-se-ia de usurpação dos poderes do Congresso pelo presidente e subordinação daquele a este; (ii) não haveria esta intenção expressa do Executivo, tal situação decorreria da necessidade de impor um corretivo à inércia do Legislativo e (iii) seria um instrumento institucional que garante o controle da agenda pelo Executivo sem que isto signifique que este passaria por cima de uma maioria parlamentar. AMORIM NETO, Otavio; TAFNER, Paulo. op. cit., p. 7.

45 Para Amorim e Tafner: "Para nós, o presidencialismo brasileiro desenvolveu uma forma de interação entre Executivo e Legislativo que foge à visão clássica de que este deve controlar aquele por meio de instrumentos legais e formais, indo da simples interpelação de ministros em plenário, um papel ativo e independente das comissões na elaboração das leis, até votações contrárias às propostas do Governo". Id. Ibid., p. 29.

46 Id. Ibid. 
Contudo, para nós, apesar de reconhecermos que o controle das MPs traduzem uma nova forma de relação entre Executivo e Legislativo que traz ganhos em eficiência dentro do contexto de presidencialismo brasileiro, haveria ainda um certo desequilíbrio nesta relação. Uma outra forma de analisar o uso das MPs pelos Governos pós-Constituição, de 1988, é feita por Rennó. Segundo o Autor, as análises de Limongi e Figueiredo pecam ao analisar apenas a média do uso das MPs pelos diferentes Governos, pois neste tipo de análise não é possível verificar as variações no tempo e é sensível aos valores extremos da distribuição. Quando se analisa o uso mês a mês fica claro que o desvio padrão no Governo FHC, em que houve uma base parlamentar consolidada, é bem menor se comparada às outras administrações. Nos Governos em que reinou a instabilidade nas relações Executivo-Legislativo (sobretudo, Collor) há uma maior variação nas escolhas do Executivo dos mecanismos de formulação de leis. Isto comprovaria que o presidencialismo de coalizão ofereceria grande amplitude de ação para os presidentes, que variaria segundo o ambiente legislativo, e não padronizaria os comportamentos, tornando-os imprevisíveis. Assim, a grande crítica ao presidencialismo de coalizão seria a instabilidade dos comportamentos, sobretudo nos períodos em que a relação ExecutivoLegislativo é conflituosa. ${ }^{47}$

Além disso, não é porque existe um expresso consentimento do Legislativo que os poderes exercidos na prática pelo Executivo deixam de ser excessivos. Prova cabal disto é a desconsideração dos requisitos de relevância e urgência na edição das MPs. O Congresso não precisa mais ser o ator principal da atividade legislativa. $O$ novo contexto e finalidades do Estado levam necessariamente à predominância do Executivo nesta arena. Por outro lado, é necessário que ele tenha um papel mais ativo no controle que exerce sobre o Executivo, sob pena de desequilíbrio entre os Poderes. Mais correto seria se todos estes instrumentos de fortalecimento do Poder Executivo, aí incluído as MPs, tivessem sido acompanhados de mecanismos que fortalecessem o papel de controle do Legislativo e até mesmo sua forma de participação na elaboração de políticas públicas.

\subsubsection{Tramitação de urgência}

Há no ordenamento jurídico brasileiro três formas de solicitar urgência na tramitação de um projeto de lei. O primeiro refere-se ao $\S 1$ do art. 64 da CF/88. Segundo este dispositivo compete ao presidente da República a prerrogativa de solicitar urgência para a apreciação de projetos de sua autoria. Caso nenhuma das casas do Congresso se

47 RENNÓ, Lúcio. Críticas ao presidencialismo de coalizão no Brasil - processos institucionalmente constritos ou individualmente dirigidos? In: AVRITZER, L.; ANASTASIA, F. Reforma politica no Brasil. Belo Horizonte: UFMG, 2006. p. 266-69. 
manifeste sobre essa proposição em quarenta e cinco dias todas as demais votações ficam sobrestadas, $\S 2$ do art. 64 da CF/88. Isto acaba por dotar o Executivo de poderes de agenda legislativa muito próximos aos já examinados para a aprovação das MPs, pois obriga o Legislativo a examinar os projetos do Governo.

Os outros regimes de urgência são determinados pelo Regimento Interno da Câmara dos Deputados. O art. 151 do Regimento determina diversas possibilidades de pedir o encaminhamento de uma matéria em regime de urgência, dentre elas as reconhecidas, por deliberação do Plenário, de caráter urgente. $\mathrm{O}$ art. 155 deste documento, por sua vez, possibilita a inclusão imediata na pauta do dia de matéria considerada de relevante $e$ inadiável interesse nacional. Em ambos os casos, o inc. II, do art. 154 do Regimento Interno da Câmara dos Deputados garante aos líderes partidários a prerrogativa de apresentarem o pedido de urgência.

A colocação de determinadas matérias em regime de urgência produz mais uma vez uma posição privilegiada do Executivo na arena legislativa. Em primeiro lugar, transfere a deliberação da matéria das comissões para o plenário. São nas comissões, contudo, que os parlamentares possuem mais capacidade de influenciar projetos de lei. Seu poder de apresentar emendas, por exemplo, é muito mais limitado no plenário. ${ }^{48}$ Centralizam-se assim as decisões na arena do Legislativo e inviabiliza-se com isso, também, o poder de veto de uma minoria, que seria possível diante do poder terminativo das comissões. Em segundo lugar, os projetos de iniciativa do presidente, que passam por regimes de urgência ou ordinário, recebem um tratamento diferenciado. Eles seriam aprovados muito mais rapidamente que os do Legislativo. ${ }^{49}$ Os projetos do Executivo contariam com os maiores índices de aprovação. ${ }^{50}$

Essa preponderância do Executivo, no que concerne à produção legislativa, ocorre porque a estrutura interna do Legislativo é extremamente centralizada nas mãos dos líderes partidários. ${ }^{51}$ Isso diminuiria os riscos do Executivo, pois este pode mais facilmente negociar junto aos líderes partidários. Portanto, o regime de urgência se insere no conjunto de prerrogativas do Executivo na arena legislativa que garantem a sua dominação quase absoluta no processo legislativo. ${ }^{52}$

48 FIGUEIREDO, Argelina Cheibub; LIMONGI, Fernando. Executivo e Legislativo na nova ordem constitucional. Rio de Janeiro: FGV, 1999. p. 29.

49 "Ante a expectativa de morosidade dos trabalhos, o colégio de líderes intervém na tramitação da matéria e força sua rápida deliberação em plenário. Como essa intervenção é previamente negociada, a participação dos parlamentares em plenário depende dos resultados das negociações entre os líderes". (grifos nossos). Id. Ibid., p. 68.

50 Id. Ibid., p. 48-55.

51 Id. Ibid., p. 56.

52 Correlato a este tema, é interessante ver os trabalhos acerca da produção legislativa diante da predominância do Executivo nesta arena. Neste sentido vide: AMORIM NETO, Otavio; SANTOS, Fabiano. A produção legislativa no Congresso: entre paróquia e Nação. In: VIANA. L. W. (Org.) A democracia e os três poderes 


\subsubsection{O Orçamento}

A Constituição estabelece a competência exclusiva do Executivo para iniciar qualquer legislação pertinente à matérias orçamentárias, incluindo-se aí o Plano Plurianual (PPA), a Lei de Diretrizes Orçamentárias (LDO), a Lei Orçamentária Anual (LOA) e as Leis de Crédito. Diante do monopólio de iniciativa dada ao Executivo, o Constituinte garantiu o direito dos parlamentares apresentarem emendas aos projetos enviados pelo primeiro, ${ }^{53}$ art. 116 da CF/88. Esta possibilidade é encarada por grande parte da literatura como o mecanismo que possibilitaria as relações fisiológicas e clientelistas entre os parlamentares e o Executivo dentro do processo orçamentário. ${ }^{54}$

Tomaremos como padrão de análise o procedimento de aprovação do Projeto de Lei Orçamentária (PLO), que é o projeto de orçamento para o exercício fiscal do ano subseqüente.

Cabe ao presidente da República o envio do PLO ao Congresso até o dia 30 de agosto. É a Secretaria de Orçamento Federal (SOF) a responsável pela feitura do PLO. Será ela que definirá a coordenação entre receitas e despesas e a alocação dos recursos disponíveis para os ministérios e programas do Governo. ${ }^{55}$ Os ministérios, por sua vez, apresentam suas propostas à SOF dentro dos limites estabelecidos por esta. Finalmente, a SOF consolida todas as propostas em um só documento. Cumpre observar que, já neste momento, parlamentares e grupos de pressão apresentam seus pedidos junto aos ministérios para terem seus projetos incluídos no orçamento do Governo. ${ }^{56}$

A competência do Executivo de elaborar o PLO definirá uma posição estratégica no seu padrão de interação com o Legislativo dentro do processo orçamentário logo de início. Vejamos, enviado o PLO ao Congresso, ele será analisado pela Comissão Mista de Planos e Orçamentos Públicos (CMO). Esta será dividida em sub-relatorias definidas, segundo o projeto original do Governo mantendo-se, assim, certa simetria

no Brasil. Belo Horizonte: UFMG; Rio de Janeiro: IUPERJ/FAPERJ, 2002. p. 91-139 e também RICCI, P. O conteúdo da produção legislativa brasileira - leis nacionais ou políticas paroquiais? Dados: revista de ciências sociais, Rio de Janeiro, v. 46, n. 4, p. 669-734, 2003.

53 Este foi um dos mecanismos encontrados pelo constituinte de reforçar o Poder Legislativo relativamente ao regime anterior, no qual o Parlamento não passava de mero chancelador do projeto do Governo, uma vez que não era permitido aos seus membros apresentar qualquer modificação.

54 PEREIRA, Carlos; MUELLER, Bernardo. Comportamento estratégico em presidencialismo de coalizão: as relações entre Executivo e Legislativo na elaboração do orçamento brasileiro. Disponível em: $<$ http://www. scielo.br/scielo.php?script=sci_arttexpid=S0011-52582002000200004lng=ennrm=iso $>$. Acesso em: 11 fev. 2007. p. 5. Neste mesmo sentido vide, SERRA, José. Orçamento no Brasil: as raízes da crise. São Paulo: Atual, 1994. p. 53.

55 Idem, p. 3 e SANTOS, Maria Helena de Castro; MACHADO, E. M.; ROCHA, P. E. N. de Moura. O jogo orçamentário da União: relações Executivo-Legislativo na terra do 'pork-barrel'. In: DINIZ, e.; AZEVEDO, S. Reforma do Estado e democracia no Brasil: dilemas e perspectivas. Brasília: UNB, ENAP, 1997. p. 93.

56 PEREIRA, Carlos; MUELLER, Bernardo. op. cit., p. 3. 
destas para com os programas prioritários dos ministérios. ${ }^{57}$ Há, dessa forma, uma prédeterminação de quais programas e atividades são passíveis de receber recursos. ${ }^{58}$ Isto significa, na prática, que os parlamentares têm de necessariamente levar em consideração as prioridades do Governo, na hora de apresentarem suas emendas. Os remanejamentos orçamentários só podem ocorrer dentro de uma mesma área temática de uma subrelatoria. Logo, as emendas dos parlamentares, que são, na verdade, uma proposta de remanejamento dos recursos, como visto, não podem desconsiderar completamente as prioridades estabelecidas pelo Executivo que são refletidas nessa divisão de relatorias. ${ }^{59}$

Ao lado disso, o Governo também atuará na $\mathrm{CMO}$, mediante seus líderes que exercerão papel fundamental nas negociações com o relator-geral. ${ }^{60} \mathrm{~A}$ influência sobre o relator-geral é de suma importância para o Governo, porque é nesta figura que se concentram as decisões-chaves do orçamento. Ao elaborar o parecer preliminar sobre a proposta do Governo, o relator determina os procedimentos para a apreciação do projeto orçamentário do Executivo bem como das emendas apresentadas pelos parlamentares. ${ }^{61}$ Segundo o inc. II do $\S 3$ do art. 166 da CF/88, os parlamentares somente poderão apresentar emendas ao projeto de orçamento do Governo se indicarem os recursos necessários. Contudo, na prática, é o relator que definirá os recursos necessários ao remanejamento das receitas, segundo as propostas das emendas dos parlamentares. ${ }^{62}$ Essa definição é dada após a negociação do relator com os líderes partidários e com o Executivo. ${ }^{63}$ Assim, os cancelamentos que o parlamentar precisa indicar na emenda que apresenta para realocar recursos para as atividades que está propondo não são considerados na prática. ${ }^{64} \mathrm{O}$ poder do Executivo será ainda maior dentro desse processo, quando o relator-geral for considerado um agente da maioria que apóia o Executivo; neste caso, ele terá todo o interesse em representar o Governo. ${ }^{65}$

57 LIMONGI, Fernando; FIGUEIREDO, A. Incentivos eleitorais, partidos políticos e política orçamentária. Dados: revista de ciências sociais, Rio de Janeiro, v. 45, n. 2, p. 303-344, 2002.

58 LIMONGI, Fernando; FIGUEIREDO, A. Processo Orçamentário e comportamento legislativo - emendas individuais, apoio ao Executivo e programas do Governo. Dados: revista de ciências sociais, Rio de Janeiro, v. 48 , n. 4 , p. 737-776, 2005.

59 Neste sentido, vide LIMONGI, Fernando; FIGUEIREDO, A. Incentivos eleitorais, partidos políticos e política orçamentária. cit. (nota 57 supra), p. 321.

60 SANTOS, Maria Helena de Castro; MACHADO, E. M.; ROCHA, P. E. N. de Moura. O jogo orçamentário da União: relações Executivo-Legislativo na terra do 'pork-barrel'. In: DINIZ, e.; AZEVEDO, S. Reforma do Estado e democracia no Brasil: dilemas e perspectivas. Brasília: UNB, ENAP, 1997. p. 118.

${ }^{61}$ Id. ibid., p. 100.

${ }_{62}$ LIMONGI, Fernando; FIGUEIREDO, A. Processo Orçamentário e comportamento legislativo. cit. (nota 58 supra), p. 761.

63 SANTOS, Maria Helena de Castro; MACHADO, E. M.; ROCHA, P. E. N. de Moura. O jogo orçamentário da União. cit. (nota 55 supra), p. 103.

64 Id. Ibid.

${ }_{65}$ LIMONGI, Fernando; FIGUEIREDO, A. Incentivos eleitorais, partidos politicos e política orçamentária. cit. (nota 57 supra), p. 321. 
Ainda em relação ao processo de elaboração do orçamento, o Executivo tem a prerrogativa de vetar, no todo ou em parte selecionadas, o projeto de orçamento que recebeu emendas no Congresso. ${ }^{66}$ Isso garante um forte controle sobre o desenho final do orçamento. Este dispositivo, contudo, segundo Pereira e Mueller, não seria muito usado pelo Executivo, porque a execução dessas emendas 'indesejáveis' garantiriam uma "moeda de troca" ao Executivo, quando necessitasse do apoio parlamentar. ${ }^{67}$

OExecutivo também contaria com certo espaço de manobra deremanejamento dos recursos orçamentários mediante os créditos adicionais, ${ }^{68}$ previstos na Lei n. 4.320/64. Há três tipos de créditos adicionais: a) suplementar, que se destina ao reforço de crédito insuficiente; b) especial, destinado a despesas para as quais não haja dotação específica e c) extraordinário, destinado ao atendimento de despesas urgentes e imprevisíveis. ${ }^{69}$ Estes mecanismos institucionais permitem ao Executivo introduzir novas emendas ao orçamento realocando recursos. Em relação ao crédito suplementar, por exemplo, há a mudança na alocação orçamentária para cobrir uma dotação insuficiente. Se esta mudança estiver dentro dos limites da LOA, ela pode ser feita sem a autorização do Legislativo por decreto presidencial. ${ }^{70}$ Caso seja preciso um crédito especial, em que é necessária a aprovação da $\mathrm{CMO}$, ainda assim o Executivo estará em posição privilegiada, pois a CMO não pode alterar a destinação dos recursos nem o seu montante. ${ }^{71}$ Ao lado disso, é necessária a maioria simples para a aprovação desse crédito, o que não se demonstra difícil para um Governo com uma base parlamentar majoritária. ${ }^{72} \mathrm{O}$ Executivo ainda levaria a vantagem de concentrar as informações sobre a disponibilidade dos recursos. ${ }^{73}$ Ao utilizar excessivamente estes recursos, o Governo pode acabar por subverter as prioridades definidas pela LOA. $^{74}$

${ }_{66}$ PEREIRA, Carlos; MUELLER, Bernardo. Comportamento estratégico em presidencialismo de coalizão. cit. (nota 54 supra), p. 8.

67 PEREIRA, Carlos; MUELLER, Bernardo. Comportamento estratégico em presidencialismo de coalizão. cit., p. 17-19. Esta afirmação será mais adiante discutida quando apresentarmos o debate da literatura sobre a existência ou não deste padrão de interação entre Legislativo e Executivo no jogo orçamentário.

68 Id. Ibid., p. 3.

69 OLIVEIRA, Régis Fernandes de; HORVARTH, Estevão. Manual de direito financeiro. 4. ed. São Paulo: Revista dos Tribunais, 2001. p. 104-04.

70 PEREIRA, Carlos; MUELLER, Bernardo. Comportamento estratégico em presidencialismo de coalizão. cit., (nota 54 supra), p. 3.

71 Id. Ibid.

72 Id. Ibid.

73 Id. Ibid., p. 4.

74 SANTOS, Maria Helena de Castro; MACHADO, E. M.; ROCHA, P. E. N. de Moura. O jogo orçamentário da União: relações Executivo-Legislativo na terra do 'pork-barrel'. In: DINIZ, E.; AZEVEDO, S. Reforma do Estado e democracia no Brasil: dilemas e perspectivas. Brasília: UNB, ENAP, 1997. p. 118. (nota 55 supra), p. 113. 
Finalmente, o mecanismo institucional que garante uma grande vantagem estratégica do Executivo no jogo orçamentário é o fato de a LOA ser autorizativa e nãomandatória. ${ }^{75}$ Assim, será o Executivo que determinará quando e se vai executar todos os gastos previstos no orçamento. Além disso, a liberdade de decidir quando liberar tais verbas orçamentárias permite ao Executivo adaptar o orçamento ao contexto políticoeconômico. ${ }^{76}$

Fica patente, portanto, a posição privilegiada que o Executivo se encontra dentro do processo orçamentário. Tendo examinado o forte poder do Governo em relação ao processo orçamentário, que por si só já nos permitiria concluir que o papel do Legislativo aqui é bastante limitado, cumpre agora uma breve síntese dos estudos da literatura política que discutem a forma de intervenção dos parlamentares neste procedimento.

Como já mencionado, o $\S 2$ do art. 166 da CF/88 garante aos parlamentares o direito de apresentar emendas ao projeto orçamentário do Executivo. Contudo, esta prerrogativa não foi dada sem limites, ela só pode ser exercida se respeitadas algumas restrições que são, relativamente, ao PLO: (i) compatibilidade com o PPA e LDO, (ii) indicação de recursos necessários admitidos apenas os provenientes de anulação de despesa, excluídas as que incidem sobre (a) dotações para pessoal e seus encargos, (b) serviço da dívida e (c) transferências tributárias constitucionais para os entes Estados, Municípios e Distrito Federal.

Esta possibilidade de apresentar emendas individuais ${ }^{77}$ (§ 2 do art. 166 da $\mathrm{CF} / 88$ ) é considerada por parte da literatura como o mecanismo que viabiliza as relações clientelistas entre Executivo e Legislativo, pois a execução das emendas pelo Governo seria uma "moeda de troca" ao apoio parlamentar. Isto só seria possível porque se toma como premissa que o único fim dos parlamentares seria a busca de sua reeleição. Para tanto, os políticos durante o seu mandato buscariam levar para suas bases eleitorais o máximo possível de benefícios tangíveis. Daí ser interessante para eles que o Executivo implementasse suas emendas individuais. Garantir-se-ia, assim, através da troca de apoio do parlamentar ao Governo, a execução dessas emendas individuais que, por

75 LIMONGI, Fernando; FIGUEIREDO, A. Incentivos eleitorais, partidos políticos e politica orçamentária. cit., (nota 57 supra), p. 314-15; PEREIRA, Carlos; MUELLER, Bernardo. Comportamento estratégico em presidencialismo de coalizão. cit., (nota 54 supra), p. 11; SANTOS, Maria Helena de Castro; MACHADO, E. M.; ROCHA, P. E. N. de Moura. O jogo orçamentário da União. cit. (nota 55 supra), p. 115.

76 LIMONGI, Fernando; FIGUEIREDO, A. Incentivos eleitorais, partidos políticos e política orçamentária. cit., (nota 57 supra), p. 326.

77 Até a edição da Resolução n. 2/95 do Congresso Nacional a questão da propositura de emendas pelos parlamentares não era bem definida. Em 92, por exemplo, somente foram aceitas emendas individuais. Em 94 e 95 outros tipos de emendas, como as de partidos políticos, foram aceitas. A partir da Resolução citada, contudo, a questão se encontra mais delimitada, podem propor emendas, além dos parlamentares individualmente, as comissões permanentes, as bancadas estaduais e regionais. (PEREIRA, Carlos; MUELLER, Bernardo. Comportamento estratégico em presidencialismo de coalizão. cit., (nota 54 supra), p. 4). 
sua vez, maximizariam a chance de reeleição dos políticos. ${ }^{78}$ Tal troca seria ainda mais compreensível dentro de um sistema de Governo presidencialista em que o presidente, na falta de outros mecanismos de busca de apoio na arena legislativa, utilizar-se-ia do seu poder de executar emendas orçamentárias para garantir o apoio dos parlamentares ávidos em levar recursos às suas circunscrições eleitorais.

O Executivo usaria estrategicamente seu poder discricionário na execução das emendas parlamentares. E assim adotaria dois critérios padrões no processo de distribuição de verbas orçamentárias; o primeiro, seria o de recompensar os deputados que pertencem a sua base de coalizão e punir aqueles que não fazem parte; o segundo, consistiria em considerar a importância relativa dos partidos políticos que integram a coalizão governamental. ${ }^{79}$ Ao mesmo tempo os parlamentares usam mão desta estratégia para propor emendas destinadas a suas bases eleitorais, maximizando suas chances de reeleição. Os dados trazidos por Pereira e Mueller revelam que "quanto maior a proporção de emendas executadas de um deputado, mais vezes ele votará com o Governo", e também indicam que "os deputados que tinham bases eleitorais mais concentradas tenderam a ser mais favoráveis às preferências do Governo". "Seria a comprovação da existência de uma política clientelista e paroquial na interação entre Executivo e Legislativo. ${ }^{81}$ Cumpre ressaltar que o custo para o Executivo é baixíssimo, pois a única parte do orçamento sobre o qual é possível emendar - rubrica investimentos - representa uma parcela insignificante do montante total. Segundo os dados de Limongi e Figueiredo, elas representariam apenas $17,4 \%$ do total das emendas realizadas sob a rubrica investimentos no orçamento, enquanto que o restante, $82,6 \%$ se refere a emendas coletivas ou de relatores. ${ }^{82}$ Seria, portanto, do interesse do Executivo que os parlamentares façam emendas, só assim teriam à sua disposição essa "moeda de troca" para busca do apoio dos parlamentares. ${ }^{83}$

78 SANTOS, Maria Helena de Castro; MACHADO, E. M.; ROCHA, P. E. N. de Moura. O jogo orçamentário da União. cit., (nota 55 supra), p. 95. Neste mesmo sentido, vide PEREIRA, Carlos; MUELLER, Bernardo. Comportamento estratégico em presidencialismo de coalizão. cit., (nota 54 supra), p. 5 e SERRA, José. Orçamento no Brasil. cit. (nota 55 supra), p. 53.

79 PEREIRA, Carlos; MUELLER, Bernardo. Comportamento estratégico em presidencialismo de coalizão. cit., (nota 54 supra), p. 17. Fato interessante, trazido pelos para comprovarem sua tese, é o sistema criado no Governo FHC, o SIAL (Sistema de Acompanhamento Legislativo), que faria um balanço entre os pedidos dos deputados e a maneira como votam no Congresso. Isso reduziria os custos do Executivo que evitaria assim "o desperdício de verbas com parlamentares infiéis". p. 14.

80 Id. Ibid., p. 13-14.

81 SANTOS, Maria Helena de Castro; MACHADO, E. M.; ROCHA, P. E. N. de Moura. O jogo orçamentário da União. cit., (nota 55 supra), p. 118-21.

82 Estes dados se referem ao período que vai de 1996 a 2001,(LIMONGI, Fernando; FIGUEIREDO, Argelina. Processo Orçamentário. cit., (nota 58 supra), p. 740-42.

83 PEREIRA, Carlos; MUELLER, Bernardo. Comportamento estratégico em presidencialismo de coalizão. cit., (nota 54 supra), p. 16-17. 
Mas, como já visto anteriormente, o poder de apresentar emendas não é ilimitado. Além das restrições constitucionais já ressaltadas, a estrutura do processo orçamentário imporia outras. E, para alguns autores, esses limites seriam de tal monta que não seria possível afirmar que o gasto público brasileiro se basearia em trocas individuais de apoio por execução. ${ }^{84}$ Para Limongi e Figueiredo, a opinião de que o padrão de interação entre Executivo e Legislativo no processo orçamentário se daria sobre bases individualistas e clientelistas não se sustenta. A argumentação dos referidos autores se basearia em três pontos. No primeiro, demonstra-se que a importância das emendas individuais não é tal, a ponto delas poderem ser consideradas como a única forma do Executivo conseguir apoio para a aprovação de suas políticas dentro de um sistema presidencialista. A pequena importância das emendas individuais seria, por sua vez, demonstrada por diversos fatos. A partir da Resolução n. 2/95 elas foram bastante limitadas em relação ao seu número e montante por parlamentar - atualmente se restringe a dois milhões quanto ao seu valor e a vinte quanto ao número de emendas permitida por parlamentar. Além disso, as emendas individuais representaram um pouco mais de $15 \%$ do total do número de emendas parlamentares, ou seja, é o próprio Parlamento que prioriza as emendas coletivas. Por outro lado também, quanto à execução das emendas, verifica-se que as emendas individuais teriam uma taxa de execução menor se comparada às outras. ${ }^{85}$

Ao lado disso, não é possível auferir uma relação direta entre execução de emendas individuais e apoio dos parlamentares em votações nominais. Tal correlação só poderia ser construída em uma base partidária, pois o que se verifica é que a execução dos recursos alocados pelas emendas individuais ao orçamento favorece, justamente, membros daqueles partidos que votam favoravelmente à agenda legislativa do Governo. ${ }^{86}$ Os autores refinam este argumento, demonstrando que a liberação de verbas para a oposição não estaria relacionada positivamente à votação em favor do Executivo. Haveria também aqueles parlamentares que, apesar de fornecer um constante apoio ao Governo, teriam baixas médias de execuções de suas emendas. Ao lado disso, haveria aqueles parlamentares que, em virtude de não terem mais mandato, não seria possível que a execução de suas emendas fosse para eles uma "moeda de troca"; e, mesmo neste caso, observa-se que o Executivo consegue o apoio destes parlamentares. ${ }^{87}$ Estes fatos apenas demonstrariam que, apesar de haver uma tendência de maior execução de emendas individuais quanto maior o apoio ao Executivo, é mais correto utilizar o critério partidário para prever o comportamento dos parlamentares. Assim, a expectativa de ganho de um parlamentar na

\footnotetext{
LIMONGI, Fernando; FIGUEIREDO, Argelina. Processo orçamentário. cit., (nota 58 supra), p. 765.

Id. ibid., p. 742.

86 Id. Ibid., p. 749-58.

87 Id. ibid., p. 758.
} 
execução de suas emendas estaria muito mais relacionada à sua filiação partidária do que a troca de apoio ao Governo em cada votação.

Finalmente, o argumento de que as emendas individuais seriam uma "moeda de troca" do Executivo só poderia se sustentar se as agendas dos dois Poderes fossem conflitantes. ${ }^{88}$ Somente com a existência de duas agendas independentes, o Executivo poderia sacrificar a sua para então ser recompensado com o apoio parlamentar. Contudo, estariam longe de serem opostas. Diante do poder de coordenação do Executivo frente aos relatores do orçamento, a estrutura orçamentária seria organizada de tal forma que a oposição só poderia alocar seus recursos dentro das prioridades já estabelecidas pelo Governo. ${ }^{89}$ Dessa forma, o Executivo acabaria direcionando as emendas individuais para a sua própria agenda. Além disso, verifica-se que não há uma diferença substancial nas agendas dos diferentes partidos, seja de oposição seja de Governo. Os dados demonstram que as prioridades orçamentárias dos partidos de esquerda não seriam muito distantes das realizadas pelo Governo. ${ }^{90}$

Santos ainda oferece uma outra leitura sobre este ponto. Segundo o Autor, o controle do Executivo sobre os recursos financeiros dado pela Constituição, de 1988, retirou do Legislativo um instrumento fundamental de influência política dos parlamentares. Estes, para maximizar seu poder de barganha em relação ao Executivo, já que este possui o monopólio da distribuição de benefícios, agem em cooperação com os partidos. Isto teria efeitos sobre o padrão de recrutamento dos parlamentares; sendo pequena a capacidade do Congresso de interferir nas questões políticas mais importantes, os políticos mais experientes e os mais dotados de expertise são os que mais rapidamente deixam o Congresso. ${ }^{91}$

Apesar da divergência na literatura sobre tal tema, consideramos que algumas constatações podem ser tiradas desses estudos. Em todos parece haver uma tendência de que os parlamentares não agem de forma coordenada ou, em outras palavras, segundo um posicionamento ideológico claramente definido. Isto valeria mesmo para as análises de Limongi e Figueiredo, pois, conforme os autores, as agendas de oposição e Governo são praticamente as mesmas. Se este fato contribui para a eficiência do Governo, pelo menos em relação à aprovação de seu projeto, com certeza não o faz em relação à efetividade de um real controle e participação do Legislativo, neste processo. Finalmente, constata-se que o espaço institucional deixado para o Legislativo no processo orçamentário é muito pequeno. Ao lado dessa desvantagem, acrescentar-se-ia uma posição desfavorável

\footnotetext{
Id. Ibid., p. 759.

Id. Ibid., p. 760.

Id. Ibid., p. 761.

91 O Poder Legislativo no Presidencialismo de coalizão. Belo Horizonte/Rio de Janeiro: UFMG/IUPERJ, 2003. p. 109-39.
} 
em relação ao Executivo, no que tange ao conhecimento de dados relativos ao Tesouro público. Estes fatos aliados nos levam a concluir que, se o constituinte teve a intenção de reforçar o papel do Legislativo no processo orçamentário, este reforço não resultou no exercício de um controle efetivo do Governo. Muito menos no uso de sua prerrogativa de co-autor do planejamento. Sobre este ponto, por exemplo, Figueiredo constata que a CMO não realiza uma fiscalização rotineira do orçamento. O monitoramento da execução deste seria realizado pelas assessorias visando auxiliar, essencialmente, os parlamentares de modo individual..$^{92}$ Se houve ganhos para a governabilidade com a preponderância do Executivo, deve-se constatar que tal ponto se deu a custo de uma diminuição do papel do Legislativo.

\subsection{Patronagem - Formação do Governo (art. 84, inc. I da CF/88)}

Uma das características dos sistemas presidencialistas é a prerrogativa do presidente nomear livremente seus ministros. Como sua eleição independeria da confiança de uma maioria parlamentar, o presidente não é obrigado a nomear seus ministros de acordo com a representação dos partidos que compõe sua base no Legislativo. Tal liberdade não se verificaria nos sistemas parlamentaristas, constata-se nesse sistema que há um enorme e constante peso atribuído aos partidos, no que diz respeito à formação dos gabinetes. Nos sistemas presidencialistas, contudo, esse critério pode variar substancialmente e pode ser um dos instrumentos usados pelos presidentes para formarem sua estratégia em busca de apoio.

De acordo com Amorim, o Executivo deteria em suas mãos diversas moedas de troca para buscar o apoio dos parlamentares nos sistemas presidencialistas da América Latina, dentre eles: (i) posição estratégica dada ao participar de um Executivo, sobretudo quando se trata de um Estado com grande peso na economia, (ii) maior possibilidade técnica de influenciar e propor políticas públicas no Executivo do que nos Legislativos e (iii) o fato de não haver necessidade de renunciar o cargo legislativo para participar do Governo, devendo-se apenas pedir licença. ${ }^{93}$

No presidencialismo brasileiro não seria diferente, o inc. I do art. 84 da $\mathrm{CF} / 88$ determina que compete exclusivamente ao presidente a nomeação e a exoneração dos ministros de Estado. Assim, estes estão sob a inteira responsabilidade do presidente da República e somente a ele devem se reportar. Os padrões de recrutamento ministerial

92 FIGUEIREDO, Argelina Cheibub. Instituições e política no controle do Executivo. Dados: revista de ciências sociais, Rio de Janeiro, v. 44, n. 4, p. 689-727, 2001.

93 AMORIM NETO, Otavio. Presidencialismo e governabilidade nas Américas. Rio de Janeiro: FGV / Konrad Adenauer Stiftung, 2006. p. 26-30. 
seriam então um bom indicativo do grau de solidez legislativa de um gabinete. ${ }^{94}$ No Brasil, apesar da formação ministerial não seguir a regra da proporcionalidade, observa-se que quanto maior essa correspondência maior será a disciplina legislativa dos que integram a base do Governo. ${ }^{95}$ Essa relação seria demonstrada por um índice denominado taxa de coalescência do gabinete.

A opção de formar um gabinete de coalizão ainda interfere em outros padrões da relação Executivo-Legislativo. No País, observa-se que quanto maior for a taxa de coalescência, maior será a edição de MP com alteração do texto. Isto porque tal formação ministerial abriria a possibilidade de maior diálogo entre a base do Governo e a Presidência, como já analisamos no caso dos "alarmes de incêndio". No caso de um Governo minoritário, verificar-se-ia o contrário, o Governo recorreria mais às MPs originais. ${ }^{96}$ Contudo, essa opção só se averiguaria eficaz no curto prazo, e o exemplo clássico desse fenômeno no Brasil seria o Governo Collor. ${ }^{97}$ Portanto, quanto maior a coordenação entre Executivo e Legislativo na formação ministerial, maior será o apoio da base governamental no Governo e maior será o ajuste de preferências entre ambos os Poderes. ${ }^{98} \mathrm{E}$, contrariamente, a opção pela formação de um Governo antimajoritário indicaria uma maior tendência em utilizar mais mecanismos legislativos unilaterais e contrários às preferências das maiorias legislativas. ${ }^{99}$

\subsection{Mecanismos de controle do Legislativo sobre o Executivo}

Segundo o inc. V do art. 49 da CF/88 compete ao Congresso Nacional a sustação de atos do Poder Executivo que exorbitem o seu poder regulamentar ou os limites da delegação legislativa. Segundo Ferraz, tratar-se-ia de um controle político de constitucionalidade. ${ }^{100}$ Isto porque tal dispositivo determina a instrumentalização constitucional de um órgão para que verifique a adequação de uma atividade ou

\footnotetext{
AMORIM NETO, Otavio; TAFNER, Paulo. Governos de coalizão. cit., (nota 26 supra), p. 23.

Id. Ibid.

96 Id. Ibid., p. 23-24.

97 "Entretanto, se os presidentes detêm a alternativa constitucional de editar decretos-leis e dispõem de amplo poder de veto, sentem-se tentados a formar seus gabinetes principalmente com tecnocratas e políticos com os quais tenha laço de lealdade pessoal e distribuir aos partidos pastas ministeriais de forma não-equânime. Porém, enquanto, no curto prazo, a nomeação de ministros apartidários pode ser ótima para o chefe do Executivo, no longo prazo, contudo, esse padrão de seleção ministerial pode alienar perigosamente os partidos e o Legislativo, o que sempre constitui um risco para a estabilidade política. Os casos de Collor, no Brasil, e de Fujimori, no Peru, são muito ilustrativos a esse respeito". (AMORIM NETO, Otavio. Presidencialismo e governabilidade cit., (nota 94 supra), p. 69.

98 AMORIM NETO, Otavio; TAFNER, Paulo. Governos de coalizão cit., (nota 26 supra), p. 28.

99 Id. Ibid., p. 28.

100 FERRAZ, Ana Cândida Cunha. Conflito entre poderes: o poder congressual de sustar atos normativos do Poder Executivo. São Paulo: Revista dos Tribunais, 1994. p. 209-210.
} 
comportamento à Constituição-parâmetreo. ${ }^{101}$ Essa sustação se assemelharia, portanto, à declaração de invalidade de um ato pelo Poder Judiciário. ${ }^{102}$

Apesar do certo temor inicial da literatura em relação a esse dispositivo, ele nunca foi usado na prática; não-obstante, há alguns projetos para a sustação de atos do Poder Executivo. Logo, este mecanismo de controle do Legislativo sobre o Executivo, que a princípio provocou certo receio de abuso, é praticamente letra morta da Constituição.

Muito mais comum, entretanto, é a utilização da revisão judicial dos atos do Executivo pela oposição parlamentar mediante as ações do controle de constitucionalidade concentrado. ${ }^{103}$ Estudos apontam que os partidos e associações respondem juntos por 82,8\% das Ações Declaratórias de Inconstitucionalidade (ADIN) contra o Executivo Federal. ${ }^{104}$ Observa-se, também, que este foi um mecanismo muito utilizado pelos partidos de esquerda durante o Governo FHC. Tendo a esquerda tornado-se Governo, aumentou-se o número de ADINs propostas pelos partidos de centro e direita; contudo, há uma maior tendência dos partidos de esquerda, enquanto oposição utilizarem-se deste mecanismo. ${ }^{105}$

Outra possibilidade de fiscalização, utilizado principalmente pelos partidos de oposição, são as Comissões Parlamentares de Inquérito (CPI). Figueiredo ao analisar o uso das CPIs nos Governos pós-Constituição, de 1988, observa que a maioria das que envolviam questões mais importantes e diretamente relacionadas às agências do Governo ou ficaram sem conclusão ou nem mesmo chegaram a ser instaladas durante o período analisado (1988-1999). ${ }^{106}$ A Autora afirma, diante deste quadro, que apesar da Constituição, de 1988, dotar o Legislativo de um grande poder de fiscalização, a maior concentração de poder na Presidência e a centralização do processo decisório no Congresso aumentam a capacidade do Governo para controlar a coalizão que o apóia e esvaziar a ação da oposição ${ }^{107} \mathrm{O}$ poder de veto da oposição no sistema presidencialista brasileiro pensado na perspectiva da separação rígida de Poderes parece estar muito aquém do que se imagina. Fazer oposição se tornou privilégio de apenas alguns poucos partidos que conseguem competir efetivamente para as eleições do próximo Governo. ${ }^{108}$

\footnotetext{
101 Id. Ibid., p. 209.

102 Id. Ibid. Ressalte-se que a referida autora parece se posicionar contra tal dispositivo, segundo ele como se trata de controle de constitucionalidade, a competência final para determinar o vício de constitucionalidade é do Supremo Tribunal Federal (STF). Além disso, trata-se de um controle de constitucionalidade exercido por um órgão político, o que por si só causaria repúdio.

103 FIGUEIREDO, Argelina Cheibub. Instituições e política. cit., (nota 92 supra), p. 713-14.

104 VIANNA, L. Werneck; BURGOS, Marcelo Baumann; SALLES, Paula Martins. Dezessete anos de judicialização da política. Caderno Cedes - IUPERJ, Rio de Janeiro, n. 8, 2006.

105 Id. Ibid.

106 FIGUEIREDO, Argelina Cheibub. Instituições e política. cit., (nota 92 supra).

107 Id. Ibid.

108 LIMONGI, Fernando. Presidencialismo e Governo de coalizão. In: AVRITZER, L.; ANASTASIA, F. (Orgs.). Reforma política no Brasil. Belo Horizonte: UFMG, 2006. p. 237-57.
} 
3. Governabilidade, mas a que preço?

Não pretendemos opinar sobre a adequação do sistema de Governo, contudo, o quadro institucional que acabamos de traçar coloca em questão se o diagnóstico de ingovernabilidade no Brasil ainda é válido. Como vimos, a relação Executivo/Legislativo é muito complexa e outros fatores além da separação de Poderes contam. Mesmo tendo nos detido somente aos mecanismos constitucionais que compõem essa relação, a análise deles já se revela muito difícil devido à quantidade deles e às diferentes análises que sobre eles recaem. Sabemos, portanto, dos limites de nossa análise. Além disso, muitos mecanismos importantes não foram aqui examinados, diante da necessidade de delimitarmos nosso objeto de estudo. Apenas para citar alguns deles, não tratamos dos efeitos do poder de veto do presidente sobre o processo legislativo. ${ }^{109}$ Assim, nos ateremos a fazer considerações sobre os mecanismos que levantamos.

Tendo isso em mente, tendemos a concordar com a opinião de Figueiredo de que a centralização do processo decisório nas mãos do Executivo, sob a égide da Constituição, de 1988, impediu que o Congresso exercesse um papel efetivo de controle ou que participasse como co-autor na formulação de políticas públicas. ${ }^{110} \mathrm{O}$ poder de agenda do Executivo aliado à patronagem praticamente inviabiliza a existência de um Legislativo fiscalizador e co-autor da agenda governamental. ${ }^{111}$ Para nós fica claro, diante da análise que realizamos, a existência de um desequilíbrio entre os Poderes a favor do Executivo e em prejuízo do Legislativo. Compreendemos que o centro do poder decisório foi irremediavelmente deslocado para o Executivo no contexto do Estado Social, contudo, no Brasil este deslocamento não foi feito com a redefinição do papel do Legislativo, que continua sendo o Poder que detém maior representatividade da sociedade.

109 Sobre a prática institucional do veto no Brasil temos notícia de apenas dois trabalhos: LAMOUNIER, Leonardo Alves. Poder de agenda, poder de veto e relações Executivo-Legislativo no Brasil contemporâneo - presidencialismo de coalizão e reciprocidade estratégica. 2005. Tese (Doutorado) - Faculdade de Filosofia e ciências humanas da UFMG, Belo Horizonte e GROHMANN, L. G. M. O veto presidencial no Brasil: 1946-1964 e1990-2000. 2003. Tese (Doutorado) - Instituto Universitário de Pesquisas do Rio de Janeiro, Rio de Janeiro.

110 "No entanto, os sistemas presidencialistas evoluíram de forma contrária aos desígnios de seus idealizadores. Hoje, faltam na maioria dos países as condições básicas para o funcionamento adequado de um sistema de fiscalização e equilíbrio entre os poderes. Em primeiro lugar, porque os partidos políticos tornaram-se a principal base de Governo e os Governos representativos assumiram a forma de democracias partidárias, e em segundo porque o desenho constitucional dos sistemas presidencialistas vem tomando a direção contrária àquela antecipada por seus pais fundadores: a concentração de poder decisório no Executivo tornou-se um traço comum nesses regimes. Essa estrutura institucional afeta o desempenho do Congresso como agência horizontal de controle do Executivo". (grifos nossos) In Agendas, instituições políticas e cit. (nota 16 supra), p. 80 .

111 SANTOS, F. O Poder Legislativo no presidencialismo de coalizão. Belo Horizonte / Rio de Janeiro: UFMG, IUPERJ, 2003. p. 58-83. 
Vejamos alguns pontos que foram levantados neste trabalho e que parecem indicar a conclusão acima.

Mesmo no trabalho de Limongi e Figueiredo acerca da relação Executivo e Legislativo no processo orçamentário, constata-se uma tendência em relacionar execução das emendas individuais com apoio ao Executivo nas votações de interesse deste, ainda que se argumente que tal relação se dá sobre bases partidárias. Esta tendência conjugada com a verificação de que não há agendas conflitivas no orçamento, nem mesmo entre oposição e Governo, e com o pequeno espaço de negociação que é deixado ao Parlamento nos leva necessariamente à conclusão de que aqui o Congresso não é um co-autor no planejamento orçamentário e muito menos exerceria um papel efetivo de controle sobre o Executivo.

Quanto às MPs, apesar de haver certo controle por parte do Legislativo mediante os mecanismos de "alarme de incêndio" e que seriam comprovados pela taxa de reedição com revisão das MPs, nos parece que a completa desconsideração dos requisitos de relevância e urgência pelo Executivo, na prática constitucional, são o sintoma de que o padrão de interação entre Executivo e Legislativo não se dá com a estrita observância dos preceitos constitucionais. A mesma observação pode ser feita sobre o uso da tramitação de urgência, seja pedida pelos líderes, seja pelo próprio presidente, no processo legislativo. $\mathrm{O}$ completo desuso do dispositivo previsto pelo inciso V, do art. 49 da Constituição Federal, também é um indicativo de que o Legislativo não exerce um efetivo controle sobre os atos do Executivo.

Isto se ficarmos apenas nas críticas impostas ao modelo de presidencialismo de coalizão que possibilita a preponderância do Executivo na arena legislativa. Devese ainda considerar as críticas quanto à instabilidade deste modelo, pois ainda estaria suscetível a um Governo que decida governar unilateralmente, já que detém um grande poder legislativo, como ocorreu no Governo Collor, e que ameace seriamente a estabilidade democrática do sistema. ${ }^{112}$

Mesmo tendo sido intenção expressa do constituinte de fortalecer o Legislativo seja em relação ao seu papel de controle, seja em relação ao seu papel de co-autor do planejamento do desenvolvimento, a prática constitucional demonstra que o Legislativo não vem exercendo bem esse papel. Apesar dos mecanismos de preponderância do Executivo na arena legislativa terem trazido enormes ganhos para a eficiência do Governo, em muito se perdeu em desempenho democrático quando o papel do Legislativo foi minimizado. Com isto, não estamos afirmando que a dominação do Executivo se deu com a usurpação das competências do Legislativo. Tal delegação se deu com a concordância

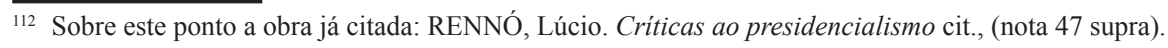


expressa deste, o que não quer dizer que isto não tenha outras implicações no âmbito democrático. O fato é que existem elementos centrífugos com potencial poder de veto no sistema de Governo brasileiro que são amenizados pelos mecanismos de preponderância do Executivo. E estes, por sua vez, acabam por enfraquecer o papel do Legislativo seja como formador de consenso em torno de políticas públicas seja como fiscalizador dos atos do Executivo. Neste mesmo sentido, Santos defende que o papel exercido pelo Legislativo em uma sociedade diz muito sobre a concepção de democracia subjacente a uma determinada ordem política, se mais inclusiva ou-não. Para ele, haveria uma certa contradição em torno das escolhas institucionais no Brasil, o dilema brasileiro, de um lado a escolha constitucional - sistema de Governo, sistema eleitoral, regime congressual e organização territorial - teria apontado para uma democracia com alto grau de dispersão do poder; mas, por outro lado, as escolhas procedimentais apontariam no outro sentido. ${ }^{113}$ Resta saber se este modelo é ou-não viável, sobretudo, se consideramos que o Brasil se enquadra num tipo de modelo consensual, dentro dos modelos de Lijphart, ${ }^{114}$ e que a eficiência deste modelo é medida pela possibilidade de gerar um efetivo consenso entre os diversos atores do jogo democrático. ${ }^{115}$

113 SANTOS, F. O Poder Legislativo no presidencialismo de coalizão. Belo Horizonte / Rio de Janeiro: UFMG, IUPERJ, 2003. (nota 111 supra), p. 208-214.

114 Segundo Lijphart encontra-se nas democracias atuais dois padrões pelos quais uma democracia poderia funcionar. A primeira forma obedece ao princípio de que é a maioria do povo que governa, seriam as democracias majoritárias. Na segunda forma, diferentemente, prevalece a vontade do maior número possível, seriam as democracias consensuais. As diferenças entre elas se dariam pela análise das escolhas institucionais de uma sociedade, haveria duas dimensões nas quais as variáveis institucionais enquadrarse-iam: dimensão executivos-partidos e federal-unitária. Na primeira as diferenças seriam as seguintes - (i) concentração de gabinetes monopartidários de maioria versus distribuição do Poder Executivo em amplas coalizões multipartidárias; (ii) Relações entre Executivo e Legislativo em que o Executivo é o predominante versus relações equilibradas entre ambos os Poderes; (iii) sistemas bipartidários versus sistemas multipartidários; (iv) sistemas eleitorais majoritários e desproporcionais versus representação proporcional e (v) sistemas de grupos de interesse pluralistas, com livre concorrência entre grupos versus sistemas coordenados e 'corporativistas' visando ao compromisso e à concertação. No que tange à segunda dimensão: (i) Governo unitário e centralizado versus Governo federal e descentralizado; (ii) concentração do Poder Legislativo numa legislatura unicameral versus divisão do Poder entre duas casas igualmente fortes, porém diferentemente constituídas; (iii) constituições flexíveis, que podem receber emendas por simples maiorias, versus constituições rígidas, que só podem ser modificadas por maiorias extraordinárias; (iv) sistemas em que as legislaturas têm a palavra final sobre a constitucionalidade da legislação versus sistemas nos quais as leis estão sujeitas à revisão judicial de sua constitucionalidade, por uma corte suprema ou constitucional e (v) bancos centrais dependentes do Executivo versus bancos centrais independentes. LIJPHART, Arendt. Modelos de democracia: desempenho e padrões de Governo em 36 países. Tradução de Roberto Franco. Rio de Janeiro: Civilização brasileira, 2003. p. 19-21.

115 É claro que o Brasil não é um modelo puro de democracia consensual, há diversas variáveis institucionais que são consideradas como típicas dos modelos majoritários; talvez mais correto seria denominar o Brasil como um modelo misto. Neste aspecto, nos parece correta a análise de Santos (nota 111 supra) acerca do dilema institucional brasileiro. Contudo, se considerarmos as escolhas constitucionais somente, parece haver uma clara inclinação para o tipo consensual. 
Para nós, portanto, se uma reforma no sistema político brasileiro deve ser realizada, ela deve ser feita de forma a transformar o Legislativo em um contrapeso real ao Executivo e também de forma a torná-lo um ator capaz de participar, efetivamente, da formulação da agenda política no Brasil sem que com isto se perca em eficiência governamental. É incontestável que o Executivo tem grande sucesso na arena legislativa desde a Constituição, de 1988; portanto, não cabe mais falar em reforma política para dar mais governabilidade ao Governo. Contudo, deve-se ressaltar que o argumento de possível agenda negativa que o Governo deixaria de levar ao Congresso por antever a sua oposição, ainda está aberto.

De qualquer forma, os mecanismos constitucionais que levantamos aqui e os infraconstitucionais apontados por Figueiredo e Limongi sobre a força dos líderes partidários no Congresso, levam à inexorável conclusão de que o problema brasileiro não é a separação do Executivo e Legislativo, oriunda do sistema presidencialista. Somos governáveis, mas cumpre ainda perguntar o quanto esta interação está longe do ideal democrático, sobretudo quando analisamos o papel atualmente exercido pelo Congresso. Nos parece pertinente o ponto de Santos sobre o modelo democrático de uma sociedade e o papel que ela dá ao seu Legislativo. De tudo que analisamos, ainda fica a impressão de que o Legislativo, por mais que atue em bases partidárias, não atua segundo uma base ideológica, mas movido pela patronagem.

Como afirmamos anteriormente, a questão é extremamente complexa, pois dependente de inúmeras variáveis. Nosso objetivo foi apenas o de destacar alguns pontos trazidos pela literatura, no que tange a interação Executivo-Legislativo sob a Constituição, de 1988, e extrair algumas considerações do que foi observado. Do levantamento que fizemos podemos concluir que o argumento da ingovernabilidade não cabe mais; agora impõe-se outro: que preço pagamos pela eficiência do Governo?

São Paulo, outubro de 2007.

Referências

ABRANCHES, Sérgio Henrique. O presidencialismo de coalizão: o dilema institucional brasileiro. Dados: revista de ciências sociais, Rio de Janeiro, v. 3, n. 1, 1988.

ACKERMAN, Bruce. The new separation of powers. Havard Law Review, v. 113, n. 3, jan. 2000.

ALMEIDA, Fernanda Dias Menezes de. Competências na Constituição de 1988. São Paulo: Atlas, 1991.

AMARAL JR., José Levi Mello do. Medida provisória e sua conversão em lei: a Emenda Constitucional n. 32 e o papel do Congresso Nacional. São Paulo: Revista dos Tribunais, 2004. 
AMORIM NETO, Otavio. Presidencialismo e governabilidade nas Américas. Rio de Janeiro: FGV, Konrad Adenauer Stiftung, 2006.

; TAFNER, Paulo. Governos de coalizão e mecanismo de alarme de incêndio no controle legislativo das Medidas Provisórias. Disponível em: <http://www/scielo.br/pdf.dados/v45n1/ a01v45n1. pdf>. Acesso em: 12 fev. 2007.

ARANTES, Rogério Bastos. O Judiciário e a política no Brasil. São Paulo: Idesp/Sumaré/FAPESP/ Educ, 1997.

BAKER, Andy. Reformas liberalizantes e apoio presidencial - a politização dos debates da política econômica no Brasil. Dados: revista de ciências sociais, Rio de Janeiro, v. 45, n. 1, p. 77-98, 2002.

BONAVIDES, Paulo. Do Estado Liberal ao Estado Social. 7. ed. São Paulo: Malheiros, 2004.

BROWN, B. E. L'Etat et la vie politique aux Etats-Unis. Tradução de Malie Montagutelli. Paris: PUF, 1994.

CHEIBUB, José Antonio; PRZEWORSKI, Adam; SAIEGH, Sebastian. Governos de coalizão nas democracias presidencialistas e parlamentaristas. Dados: revista de Ciências Sociais, Rio de Janeiro, v. 45, n. 2, p. 187-218, 2002.

CLÈVE, Clémerson Merlin. Atividade legislativa do Poder Executivo no Estado contemporâneo e na Constituição de 1988. 2. ed. São Paulo: Revista dos Tribunais, 2000.

DENENBERG, R. V., Introduction au Système politique des Etats-Unis. Tradução de James Pharrar. Paris: Economica, 1979.

DICKINSON, M. J. The President and the Congress. In: NELSON, M. (Org.). The Presidency and the political system. 8. ed. Washington: CQ, 2006.

DINIZ, Eli. Governabilidade, democracia e Reforma do Estado: os desafios da construção de uma nova ordem no Brasil nos anos 90. In: DINIZ, E.; AZEVEDO, S. de (Org.). Reforma do Estado e democracia no Brasil: dilemas e perspectivas. Brasília: UNB, 1997.

FARIA, JOSÉ EDUARDO (Org.). Direitos Humanos, direitos sociais e justiça. São Paulo: Malheiros, 2002.

. Direito e economia na democratização brasileira. São Paulo: Malheiros, 1993.

FAVOREU, L. (Coord.). Droit constitutionnel. 7. ed. Paris: Dalloz, 2004.

FERRAZ, Ana Cândida Cunha. Conflito entre Poderes: o poder congressual de sustar atos normativos do Poder Executivo. São Paulo: Revista dos Tribunais, 1994.

FERREIRA FILHO, Manoel Gonçalves. Curso de direito constitucional. 18. ed. São Paulo: Saraiva, 1990. . A democracia no limiar do século XXI. São Paulo: Saraiva, 2001. 
. O parlamentarismo. São Paulo: Saraiva, 1993.

. Constituição e governabilidade: ensaio sobre a (in)governabilidade brasileira. São Paulo: Saraiva, 1995.

FIGUEIREDO, Argelina Cheibub; LIMONGI, Fernando. Executivo e Legislativo na nova ordem constitucional. Rio de Janeiro: FGV, 1999.

; VALENTE, Ana Luzia. Governabilidade e concentração de poder institucional:

o Governo FHC. Tempo social: revista de sociologia da USP, São Paulo, v. 11, n. 2, p. 49-62, out. 1999.

. Agendas, instituições políticas e desempenho do Governo na democracia do Governo. In: REIS, E.; ZILBERMAN, R. (Org.). Retratos do Brasil. Porto Alegre: PucRS, 2004.

. Instituições e política no controle do Executivo. Dados: revista de ciências sociais, Rio de Janeiro, v. 44, n. 4, p. 689-727, 2001.

. Democracia ou reformas? Alternativas democráticas à crise política 1961-1964. São Paulo: Paz e Terra, 1993.

FISHER, Louis. Constitutional Conflicts between the Congress and the President. 4. ed. Lawrence: University Press of Kansas, 1997.

GOMES, Sandra. O Impacto das Regras de Organização do Processo Legislativo no Comportamento dos Parlamentares: Um Estudo de Caso da Assembléia Nacional Constituinte (1987-1988). Dados: revista de ciências sociais, Rio de Janeiro, v. 49, n. 1, p. 193-224, 2006.

GROHMANN, Luís Gustavo Mello. O veto presidencial no Brasil-1946-1964 e1990-2000. Tese (Doutorado) - Instituto Universitário de Pesquisas do Rio de Janeiro, Rio de Janeiro, 2003.

HAMILTON, A.; JAY, J.; MADISON, J. O Federalista: um comentário à Constituição americana, Tradução de Reggy Zacconi de Moraes. Rio de Janeiro: Nacional de Direito, 1959.

HORTA, Raul Machado. Direito Constitucional. 4. ed. Belo Horizonte: Del Rey, 2003.

KINZO, Maria D’Alva Gil. Governabilidade, estrutura institucional e processo decisório no Brasil. Parecerias Estratégicas, Brasília, v. 1, n. 3, jun. 1997.

LAMOUNIER, Bolívar. Os trabalhos da Comissão Afonso Arinos. In: FORTES, L. R. S.; NASCIMENTO, M. M. do. A Constituinte em debate: colóquio realizado de 12 a 16/05/86, por iniciativa do departamento de filosofia da USP. São Paulo: Sofia SEAF, 1987.

. Estrutura institucional e governabilidade na década de 1990. In: REIS VELLOSO, J. P. dos. (Coord.). O Brasil e as reformas politicas. Rio de Janeiro: José Olympio, 1992.

LAMOUNIER, Leonardo Alves. Poder de agenda, poder de veto e relações Executivo-Legislativo no Brasil contemporâneo - presidencialismo de coalizão e reciprocidade estratégica. Tese (Doutorado) - Faculdade de Filosofia e ciências humanas da UFMG, Belo Horizonte, 2005. 
LEAL, Vitor Nunes. Coronelismo, enxada e voto: o município e o regime representativo no Brasil, 3. ed. Rio de Janeiro: Nova Fronteria, 1997.

LIJPHART, Arendt (Org.). Presidential versus parliamentary government. New York: Oxford, 1992.

. Las democracias contemporáneas. Tradução de Elena de Grau. Ariel: Barcelona, 1987.

. Modelos de democracia: desempenho e padrões de Governo em 36 países. Tradução de Roberto Franco. Rio de Janeiro: Civilização brasileira, 2003.

LIMONGI, Fernando. Formas de Governo, leis partidárias e processo decisório. Revista Brasileira de Informação Bibliografia em ciências sociais, São Paulo, n. 41, 1996.

. A democracia no Brasil: presidencialismo, coalizão partidária e processo decisório, disponível em: $<$ http/www.cebrap.org.Br/imagens/Arquivos/a_democracia_no_brasil.pdf $>$. Acesso em: 11 fev. 2007.

. Presidencialismo e Governo de coalizão. In: AVRITZER, L.; ANASTASIA, F. (Coord.). Reforma política no Brasil. Belo Horizonte: UFMG, 2006.

; FIGUEIREDO, Argelina. Incentivos eleitorais, partidos políticos e política orçamentária. Dados: revista de ciências sociais, Rio de Janeiro, v. 45, n. 2, p. 303-344, 2002.

. Processo Orçamentário e comportamento legislativo - emendas individuais, apoio ao Executivo e programas do Governo. Dados: revista de ciências sociais, Rio de Janeiro, v. 48, n. 4, p. 737-776, 2005.

LINZ, Juan J. The perils of presidentialism. In: LIJPHART, Arend. Parliamentary versus presidential government. Oxford: Oxford University, 1995.

LOCKE, J. Segundo tratado sobre o Governo civil e outros escritos: ensaio sobre a origem, os limites e os fins verdadeiros do Governo civil. Tradução de Magda Lopes e Marisa Lobo da Costa. Petrópolis: Vozes, 1994.

LOEWENSTEIN, Karl. Teoria de la constitucion. Tradução de Alfredo Gallego Anabitarte. Barcelona: Ariel, 1964.

MAINWARING, S.; M. SHUGART, S. (Org.). Presidentialism and democracy in Latin America. Cambridge, 1997.

. Multipartism in Brazil. In: MAINWARING, S.; SHUGART, M. S. (Org.). Presidentialism and democracy in Latin America. Cambridge, 1997.

MELO, Marcus André. O sucesso inesperado das reformas de segunda geração: federalismo, reformas institucionais e política social. Dados: revista de ciências sociais, Rio de Janeiro, v. 48, n. 4, p. 845-889, 2005. 
MILKIS, S. M.; NELSON, M. The american Presidency: origins and development 1776-2000. 4. ed. Washington: CQ, 2003.

MONTESQUIEU, C. B. de. O Espírito das Leis. Tradução de Fernando Henrique Cardoso e Leôncio Martins Rodrigues. Brasília: UNB, 1982.

MORAIS, Alexandre. Presidencialismo. São Paulo: Atlas, 2004.

OGG, F. A.; RAY, P. O. Essentials of American government. 4. ed. New York/London: D. AppletonCentury Company, 1943.

OLIVEIRA, Régis Fernandes de; HORVARTH, Estevão. Manual de direito financeiro. 4. ed. São Paulo: Revista dos Tribunais, 2001.

PALERMO, Vincente. Como se governa o Brasil - o debate sobre instituições políticas e gestão de Governo. Dados: revista de ciências sociais, Rio de Janeiro, v. 43, n. 3, 2000.

PEREIRA, Carlos; MUELLER Bernardo. Comportamento estratégico em presidencialismo de coalizão: as relações entre Executivo e Legislativo na elaboração do orçamento brasileiro. Disponível em: $<$ http://www.scielo.br/scielo.php?script=sci_arttexpid=S0011-52582002000200004 1 lng=eṇnrm=iso $>$. Acesso em: 11 fev. 2007.

PESSANHA, Charles. O Poder Executivo e o processo legislativo nas constituições brasileiras: teoria e prática. In: VIANNA, L. W. (Org.). A democracia e os três Poderes no Brasil. Belo Horizonte: UFMG, Rio de Janeiro: IUPERJ/FAPERJ, 2002.

RAMOS, Elival da Silva. Uma nova Constituição - a proposta parlamentarista. Revista Bimestral de Investigação e cultura CONVIVIVM, n. 25.

. Perspectivas de evolução do controle de constitucionalidade no Brasil. TESE (Titular) - Faculdade de Direito, Universidade de São Paulo, 2005.

. Ação popular como instrumento de participação política. São Paulo: Revista do Tribunais, 1991.

RENNÓ, Lucio; SPANAKOS, Anthony P. Fundamentos da economia, mercado financeiro e intenção de voto - as eleições presidenciais brasileiras de 1994, 1998 e 2002. Dados: revista de ciências sociais, Rio de Janeiro, v. 49, n. 1, p. 11-40, 2006.

. Críticas ao presidencialismo de coalizão no Brasil - processos institucionalmente constritos ou individualmente dirigidos? In: AVRITZER, L.; ANASTASIA, F. Reforma política no Brasil. Belo Horizonte: UFMG, 2006.

ROSENN, K. S. Brazil's new Constitution - an exercise in Transient Constitutionalism for a Transitional Society. American Journal of Compartative Law, v. 38, 1990.

SAMPAIO, M. A. S. A EC N. 32/2001 e o diálogo entre Legislativo e Executivo acerca da medida provisória. Disponível em: <http://necon.iuperj.br/arquivos/artigos/artigo_sampaio.pdf $>$. Acesso em: 24 ago. 2007. 
SANTOS, Fabiano. Governos de coalizão no sistema presidencial - o caso do Brasil sob a égide da Constituição de 1988. In: AVRITIZER, L.; ANASTASIA, F. (Org.). Reforma política no Brasil. Belo Horizonte: UFMG, 2006.

SANTOS, Maria Helena de Castro. Governabilidade, governança e democracia: criação de capacidade governativa e relações executivo-legislativo no Brasil pós-constituinte. Disponível em: $<$ http://www.scielo.br/scielo.php?script=sci_arttext\&pid=S0011-52581997000300003\&lng=en\&nrm=iso $>$. Acesso em: 05 maio 2007.

; MACHADO, E. M.; MOURA ROCHA, P. E. N. de. O jogo orçamentário da União: relações Executivo-Legislativo na terra do 'pork-barrel'. In: DINIZ, E.; AZEVEDO, S. Reforma do Estado e democracia no Brasil: dilemas e perspectivas. Brasília: UNB, 1997.

SANTOS, Wanderley Guilherme dos. Razões da desordem. Rio de Janeiro: Rocco, 1994. . Sessenta e quatro: anatomia da crise. São Paulo: Vértice, 1986.

SARTORI, G. Engenharia Constitucional: como mudam as constituições. Tradução de Sérgio Bath. Brasília: UNB, 1996.

. Neither Presidentialism nor Parliamentarism. In: LINZ, J. J.; VALENZUELA, A. The failure of presidential democracy. Baltimore/London: Johns Hopkins University, 1994.

SERRA, José. Orçamento no Brasil: as raízes da crise. São Paulo: Atual, 1994.

SILVA, José Afonso da. Curso de direito constitucional positivo (1976). 18. ed. São Paulo: Malheiros, 2000.

SOUZA, M. Teixeira de. O processo decisório na Constituição de 1988: práticas institucionais. Revista Lua Nova, n. 58, 2003.

SOUZA JUNIOR, Cezar Saldanha. O Tribunal Constitucional como Poder: uma nova teoria da divisão dos Poderes. São Paulo: Memória Jurídica, 2002.

. A crise da democracia no Brasil: aspectos políticos. Rio de Janeiro: Forense, 1978.

TORRES, João Camilo de Oliveira. O Presidencialismo no Brasil. Rio de Janeiro: O Cruzeiro, 1962.

. Cartilha do parlamentarismo. Belo Horizonte: Itatiaia, 1962.

VIANNA, L. Werneck; BURGOS, Marcelo Baumann; SALLES, Paula Martins. Dezessete anos de judicialização da política. Caderno Cedes - IUPERJ, Rio de Janeiro, n. 8, 2006. 